\title{
A systems-based approach to parameterise seismic hazard in regions with little historical or instrumental seismicity: active fault and seismogenic source databases for southern Malawi
}

\author{
Jack N. Williams ${ }^{1}$, Hassan Mdala ${ }^{2}$, Åke Fagereng ${ }^{1}$, Luke N. J. Wedmore ${ }^{3}$, Juliet Biggs ${ }^{3}$, Zuze Dulanya $^{4}$, \\ Patrick Chindandali $^{5}$, and Felix Mphepo ${ }^{2}$ \\ ${ }^{1}$ School of Earth and Environmental Sciences, Cardiff University, Cardiff, UK \\ ${ }^{2}$ Geological Survey Department, Mzuzu Regional Office, Mzuzu, Malawi \\ ${ }^{3}$ School of Earth Sciences, University of Bristol, Bristol, UK \\ ${ }^{4}$ Geography and Earth Sciences Department, University of Malawi, Zomba, Malawi \\ ${ }^{5}$ Geological Survey Department, Zomba, Malawi
}

Correspondence: Jack N. Williams (williamsj132@cardiff.ac.uk)

Received: 5 June 2020 - Discussion started: 14 July 2020

Revised: 19 October 2020 - Accepted: 18 November 2020 - Published: 27 January 2021

\begin{abstract}
Seismic hazard is commonly characterised using instrumental seismic records. However, these records are short relative to earthquake repeat times, and extrapolating to estimate seismic hazard can misrepresent the probable location, magnitude, and frequency of future large earthquakes. Although paleoseismology can address this challenge, this approach requires certain geomorphic setting, is resource intensive, and can carry large inherent uncertainties. Here, we outline how fault slip rates and recurrence intervals can be estimated by combining fault geometry, earthquake-scaling relationships, geodetically derived regional strain rates, and geological constraints of regional strain distribution. We apply this approach to southern Malawi, near the southern end of the East African Rift, and where, although no onfault slip rate measurements exist, there are constraints on strain partitioning between border and intra-basin faults. This has led to the development of the South Malawi Active Fault Database (SMAFD), a geographical database of 23 active fault traces, and the South Malawi Seismogenic Source Database (SMSSD), in which we apply our systems-based approach to estimate earthquake magnitudes and recurrence intervals for the faults compiled in the SMAFD. We estimate earthquake magnitudes of $M_{\mathrm{W}}$ 5.4-7.2 for individual fault sections in the SMSSD and $M_{\mathrm{W}}$ 5.6-7.8 for wholefault ruptures. However, low fault slip rates (intermediate es-
\end{abstract}

timates $\sim 0.05-0.8 \mathrm{~mm} / \mathrm{yr})$ imply long recurrence intervals between events: $10^{2}-10^{5}$ years for border faults and $10^{3}-$ $10^{6}$ years for intra-basin faults. Sensitivity analysis indicates that the large range of these estimates can best be reduced with improved geodetic constraints in southern Malawi. The SMAFD and SMSSD provide a framework for using geological and geodetic information to characterise seismic hazard in regions with few on-fault slip rate measurements, and they could be adapted for use elsewhere in the East African Rift and globally.

\section{Introduction}

Earthquake ruptures tend to occur on pre-existing faults (Brace and Byerlee, 1966; Jackson, 2001; Scholz, 2002; Sibson, 1989). Thus, the identification and systematic mapping of active faults, which are then compiled with other fault attributes (e.g. slip rate and slip sense) into a geospatial active fault database, provide an important tool for assessing regional seismic hazard (Christophersen et al., 2015; Hart and Bryant, 1999; Langridge et al., 2016; Shyu et al., 2016; Styron et al., 2020; Styron and Pagani, 2020; Taylor and Yin, 2009). Not only can these databases provide information on 
the surface rupture risk (Hart and Bryant, 1999; Villamor et al., 2012), they can also be converted into earthquake sources for probabilistic seismic hazard analysis (PSHA) to forecast future levels of ground shaking (Beauval et al., 2018; Cornell, 1968; Gerstenberger et al., 2020; Hodge et al., 2015; Morell et al., 2020; Stirling et al., 2012). Furthermore, the data contained in active fault databases are inherently useful for understanding regional geological evolution (Agostini et al., 2011b; Basili et al., 2008; Taylor and Yin, 2009).

Active fault databases with worldwide coverage have been compiled (Christophersen et al., 2015; Yeats, 2012), including recent development of the Global Earthquake Model Foundation Global Active Fault Database (Styron and Pagani, 2020). However, in some regions, the fault mapping in these databases has only been performed at a coarse scale, and the fault attributes (e.g. slip rates, earthquake recurrence intervals) that are required to use them as earthquake sources in PSHA have not been measured. This partly reflects that obtaining these attributes from dating faulted surfaces and/or paleoseismology is time-intensive, requires certain geomorphic settings, and can involve large uncertainties (Cowie et al., 2012; McCalpin, 2009; Nicol et al., 2016b). Alternatively, decadal timescale fault slip rates can be estimated using geodetic data and block models where the crust is divided by mapped faults (e.g. Field et al., 2014; Wallace et al., 2012; Zeng and Shen, 2014). However, not all fault systems are covered by sufficiently dense geodetic networks to perform this analysis, the resulting slip rates may be biased by the short time over which these data have been collected relative to earthquake cycles, and/or sometimes geodetic data cannot resolve how strain is distributed (Calais et al., 2016; Morell et al., 2020; Stein et al., 2012).

In this study, we first describe the South Malawi Active Fault Database (SMAFD), which is a systematic attempt to map active faults and collate their geomorphic attributes in southern Malawi. Located within the East African Rift System (EARS), southern Malawi lies in a region specifically highlighted by Styron and Pagani (2020) as a priority area for future active fault mapping; population growth in this region as well as seismically vulnerable building stock is also driving an increased exposure to seismic hazard (Tectonic Shift RIFT2018 Report, 2019; Goda et al., 2016; Hodge et al., 2015; Kloukinas et al., 2020; Ngoma et al., 2019; Novelli et al., 2019).

Within southern Malawi itself, faults capable of hosting $M_{\mathrm{W}}$ 7-8 earthquakes have been previously identified (Hodge et al., 2019, 2020; Jackson and Blenkinsop, 1997; Wedmore et al., 2020a). However, there are currently no reports of historical surface-rupturing earthquakes, on-fault slip rate measurements, or paleoseismic investigations. Thus, in the second part of this study, we describe a new systems-based approach for combining geodetic and geological information to estimate slip rates and earthquake recurrence intervals. In particular, it may be useful for low-slip-rate interplate regions (regional slip rates $\sim 1-10 \mathrm{~mm} / \mathrm{yr}$; Scholz et al., 1986) where the instrumental record is relatively short compared with fault recurrence intervals and where earthquakes may be especially damaging (England and Jackson, 2011). It would not, however, be appropriate for low-strain intraplate settings where geodetic data cannot resolve deformation rates (Calais et al., 2016),

By applying this approach to southern Malawi, we have developed the South Malawi Seismogenic Source Database (SMSSD), which is a complementary database to the SMAFD but where the attributes (e.g. fault segmentation, earthquake recurrence intervals) are (1) targeted towards its inclusion in PSHA and (2) derived from modelling (and are therefore mutable). Notably, previous PSHA in the EARS has typically been conducted using the $\sim 65$-year-long instrumental seismic record alone (Ayele, 2017; Goitom et al., 2017; Midzi et al., 1999; Poggi et al., 2017). However, faultbased earthquake sources, such as the SMSSD, may play an important role in characterising the EARS's ever-increasing seismic risk (Goda et al., 2016; Hodge et al., 2015).

We describe the SMAFD and SMSSD together here so that the assumptions and uncertainties of our approach are clear, particularly for hazard modellers who may wish to incorporate these databases into a PSHA. This study first describes the seismotectonic setting of southern Malawi (Sect. 2), and the approach used for mapping its active faults in the SMAFD (Sect. 3). In Sect. 4, we then describe the method used to estimate fault slip rates, earthquake magnitudes, and recurrence intervals, and whose application to southern Malawi has resulted in the development of the SMSSD. The SMAFD is described in Sect. 5 along with an evaluation of fault slip rate estimates and sensitivity analysis in the SMSSD. Finally, in Sect. 6, we discuss the implication of these databases in terms of southern Malawi's seismic hazard, and the strategies needed to reduce uncertainties in these databases.

\section{Southern Malawi seismotectonics}

The SMAFD and SMSSD cover the geopolitical term "southern Malawi"; thus, they include all active faults between the southern end of Lake Malawi and the border between Mozambique and Malawi. Faults that lie close to or cross this national boundary are also included. The extent of these databases does not therefore correspond directly to the geological region of the "southern Malawi Rift", whose definition has varied in previous studies (Chapola and Kaphwiyo, 1992; Ebinger et al., 1987; Laõ-Dávila et al., 2015; Williams et al., 2019). In this section, we briefly summarise the tectonic history and seismic record in the region. 
(a)

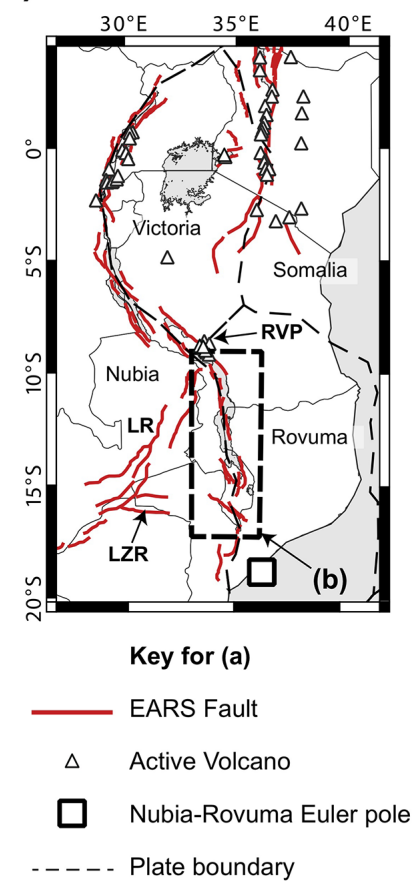

(b)

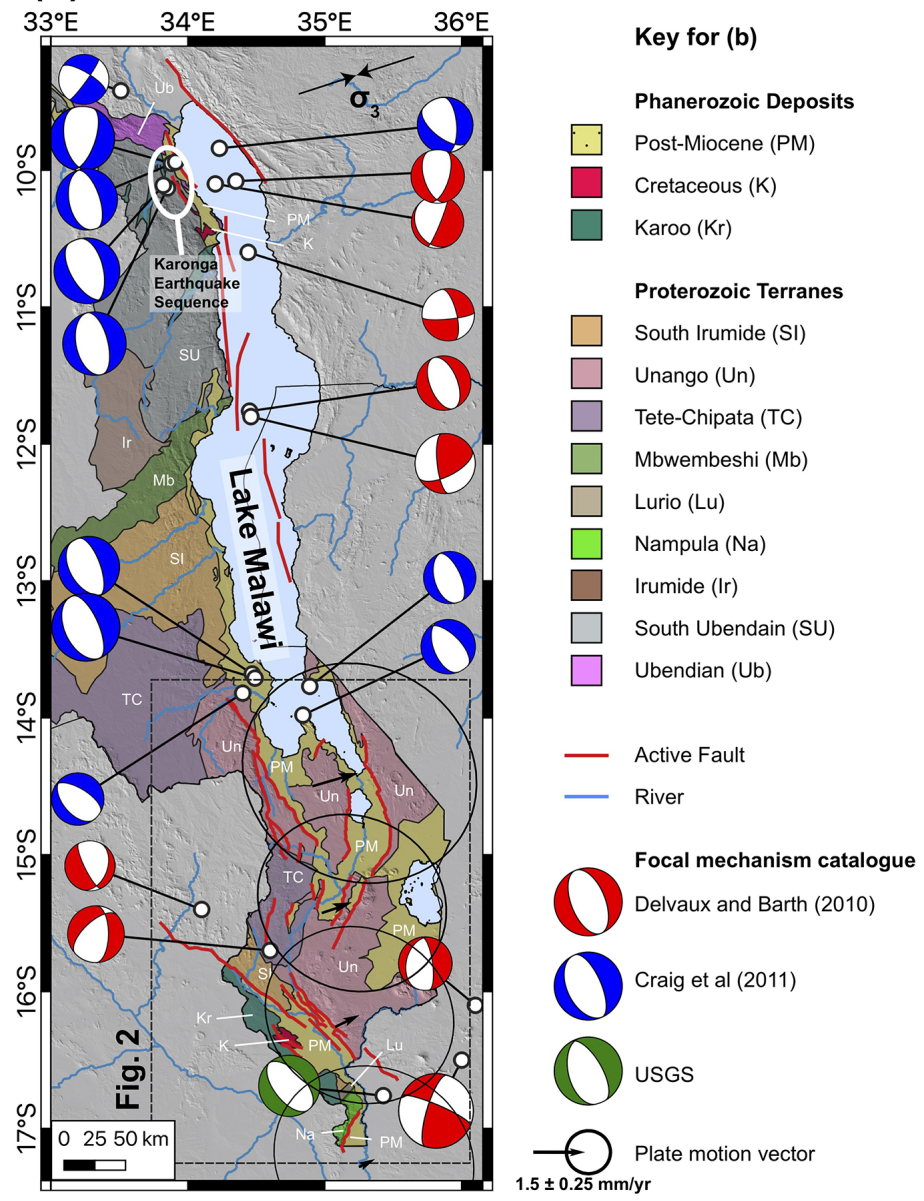

Figure 1. (a) The location of Malawi in the context of major faults in the East African Rift (Daly et al., 2020; Hodge et al., 2018a; Macgregor, 2015) and plate boundaries proposed by Saria et al. (2013). LZR represents the Lower Zambezi Rift, LR represents the Luangwa Rift, and RVP represents the Rungwe Volcanic Province. (b) A simplified geological map of Malawi, with Proterozoic terranes after Fullgraf et al. (2017). The map is underlain by the Shuttle Radar Topography Mission (SRTM) $30 \mathrm{~m}$ digital elevation model (DEM; Sandwell et al., 2011). The extent of Fig. 2 is also shown. Active faults within this area are those included in the South Malawi Active Fault Database (SMAFD). Active faults outside this region are mapped as in panel (a). Focal mechanisms collated from Delvaux and Barth (2010), Craig et al. (2011), and the U.S. Department of the Interior U.S. Geological Survey (2018). Minimum principal compressive stress $\left(\sigma_{3}\right)$ trend from focal mechanism stress inversion (Williams et al., 2019). Plate motion vector for central point of each basin in southern Malawi (Fig. S1) for the Nubia-Rovuma Euler pole (Saria et al., 2013), modelled using methods described in Robertson et al. (2016).

\subsection{Southern Malawi tectonic setting}

Southern Malawi lies towards the southern incipient end of the EARS Western Branch, where it channels the Shire River from Lake Malawi to its confluence with the Zambezi River (Dulanya, 2017; Ivory et al., 2016). This portion of the EARS is typically considered to represent the divergent boundary between the Rovuma and Nubia plates (Fig. 1a; Saria et al., 2013; Stamps et al., 2008, 2018, 2020). However, recent seismotectonic analysis suggests that the Nubia Plate can be further divided by the Lower Zambezi and Luangwa rifts into the San and Angoni plates, with the EARS in Malawi forming the Angoni-Rovuma plate boundary (Fig. 1a; Daly et al., 2020). EARS activity in southern Malawi is unlikely to have initiated prior to the mid-Pliocene $(\sim 4.5 \mathrm{Ma})$ onset of sediment accumulation in Lake Malawi's south basin (Delvaux, 1995; McCartney and Scholz, 2016; Scholz et al., 2020) and almost certainly not before the Oligocene (23-25 Ma) age of the Rungwe Volcanic Province (RVP) in southern Tanzania (Mesko, 2020; Mortimer et al., 2016; Roberts et al., 2012). The RVP, $700 \mathrm{~km}$ to the north (Fig. 1a), marks the closest surface volcanism to southern Malawi; hence, this rift section is considered to be amagmatic.

Like elsewhere in the Western Branch, the EARS in southern Malawi follows Proterozoic orogenic belts and can be divided along strike into a number of $50-150 \mathrm{~km}$ long linked basins (Ebinger, 1989). Immediately south of Lake Malawi, the EARS bifurcates around the Shire Horst within the NW- 

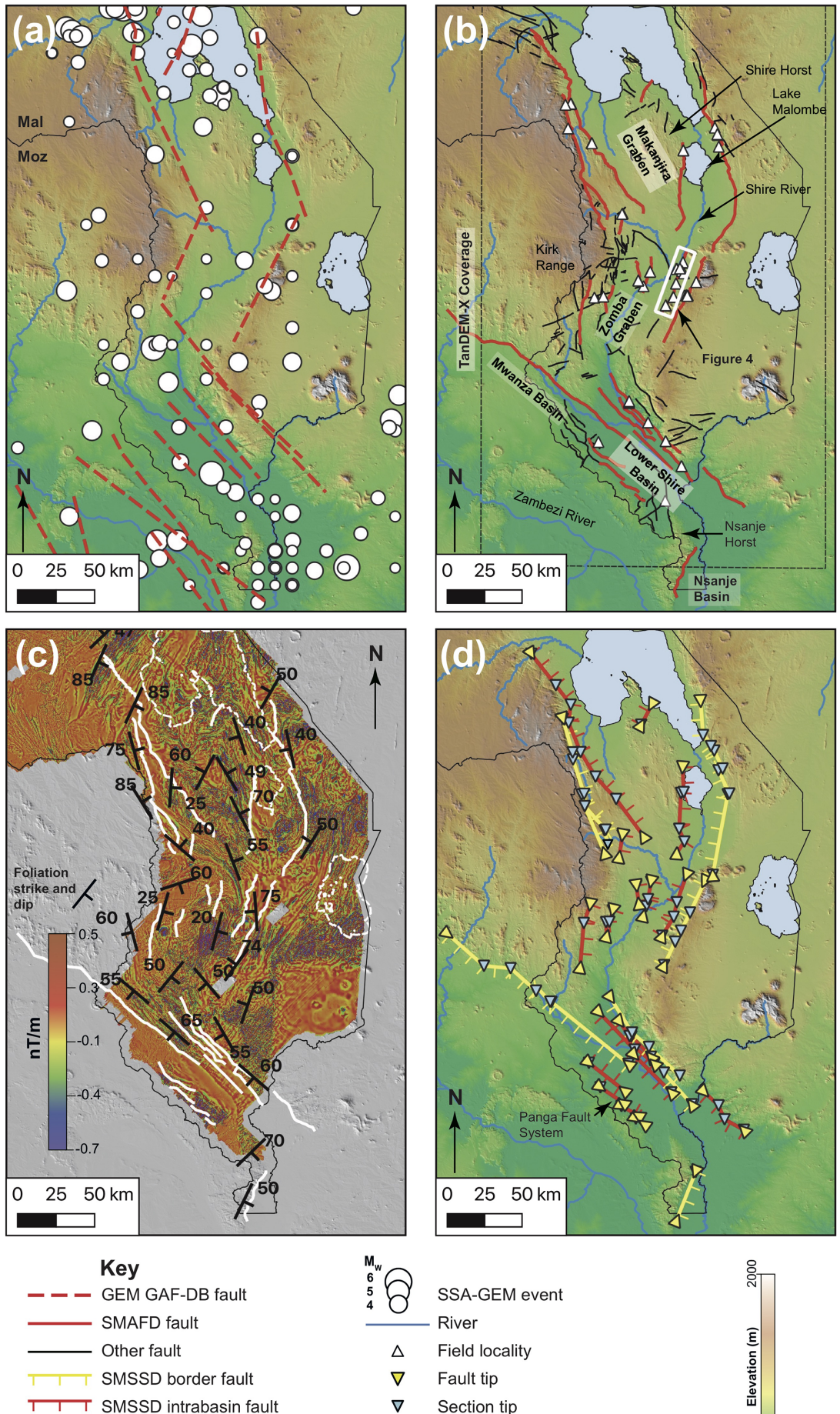

Figure 2. (a) Global Earthquake Model Global Active Fault Database map for southern Malawi (GAF-DB; Macgregor, 2015; Styron and Pagani, 2020). The sub-Saharan African Global Earthquake Model (SSA-GEM; Poggi et al., 2017) event locations are also shown. (b) Map of active fault traces compiled in the South Malawi Active Fault Database (SMAFD) with field locations and TanDEM-X coverage. Faults not interpreted to be active are also shown. (c) Aeromagnetic image created from the vertical derivative, with foliation orientations digitised from geological maps (Bloomfield, 1958, 1965; Bloomfield and Garson, 1965; Habgood et al., 1973; Walshaw, 1965). SMAFD faults shown in white and the outline of lakes are shown by dashed white lines. For full details of the acquisition of the aeromagnetic data, see Laõ-Dávila et al. (2015). (d) Simplified geometry of faults in the South Malawi Seismogenic Source Database (SMSSD), with faults sorted into border and intra-basin faults. Ticks indicate fault hanging wall. The extent of all maps is equivalent and is outlined in Fig. $1 \mathrm{~b}$. All maps are underlain by the SRTM 30 m digital elevation model. "Mal" denotes Malawi, and "Moz" denotes Mozambique. 
SE trending Makanjira Graben before following an arcuate bend in regional Proterozoic fabrics to form the NNE-SSW trending Zomba Graben (Fig. 2; Dulanya, 2017; Fullgraf et al., 2017; Laõ-Dávila et al., 2015; Wedmore et al., 2020a; Williams et al., 2019). Along strike to the south, the EARS then intersects the Lower Shire Basin, a reactivated Karooage (i.e. Permo-Triassic) basin (Castaing, 1991; Chisenga et al., 2019; Habgood, 1963; Habgood et al., 1973; Wedmore et al., 2020b), before bending around the Nsanje Horst to link up with the Urema Graben in Mozambique (Bloomfield, 1958; Steinbruch, 2010). Daly et al. (2020) proposed that the Lower Shire Basin also extends to the west along the Mwanza Basin into Mozambique where it links with the Lower Zambezi Rift and forms the San-Angoni plate boundary (Fig. 1a).

Prior to this study, the only systematic active fault mapping in southern Malawi had been conducted by Chapola and Kaphwiyo (1992) and, for the Lower Shire Basin, by Castaing (1991). These maps were subsequently incorporated by Macgregor (2015) into EARS-scale maps, and later into the Global Earthquake Model Global Active Fault Database (Styron and Pagani, 2020). However, the faults are mapped at a coarse scale (Fig. 2a), and this database does not include active faults traces identified in legacy geological maps (Bloomfield, 1965; Bloomfield and Garson, 1965; Habgood et al., 1973; Walshaw, 1965) and high-resolution digital elevation models (Hodge et al., 2019, 2020; Wedmore et al., 2020a, b).

\subsection{Southern Malawi seismicity}

There are no known historical accounts of surface-rupturing earthquakes in southern Malawi, although a continuous written record only extends to ca. 1870 (Pike, 1965; Stahl, 2010). However, in northern Malawi, the previously unrecognised St Mary Fault exhibited surface rupture following the 2009 Karonga earthquakes, a sequence consisting primarily of four shallow (focal depths $<8 \mathrm{~km}$ ) $M_{\mathrm{W}} 5.5-5.9$ events over a $13 \mathrm{~d}$ period (Fig. 1b; Biggs et al., 2010; Gaherty et al., 2019; Hamiel et al., 2012; Kolawole et al., 2018b; Macheyeki et al., 2015).

The International Seismological Centre (ISC) record for Malawi is complete from 1965 to present for events with $M_{\mathrm{W}}>4.5$ (Figs. 1b, 2a; Hodge et al., 2015), with the largest event in this record being the $1989 M_{\mathrm{W}} 6.3$ Salima earthquake (Jackson and Blenkinsop, 1993). Notably, seismicity in Malawi is commonly observed to depths far greater (30$35 \mathrm{~km}$; Craig et al., 2011; Delvaux and Barth, 2010; Jackson and Blenkinsop, 1993) than would be expected for continental crust of typical composition and geothermal gradient (10$15 \mathrm{~km}$ ). Thick cold anhydrous lower crust (Craig et al., 2011; Jackson and Blenkinsop, 1997; Njinju et al., 2019; Nyblade and Langston, 1995), localised weak viscous zones embedded within strong lower crust (Fagereng, 2013), and/or volumes of mafic material in the lower crust (Shudofsky et al.,
1987) that are velocity weakening at temperatures $<700^{\circ} \mathrm{C}$ (Hellebrekers et al., 2019) have been proposed as explanations for this unusually deep seismicity.

Earthquake focal mechanism stress inversions that encompass events from across Malawi indicate a normal fault stress state (i.e. vertical maximum principal compressive stress) with an ENE-WSW to E-W trending minimum principal compressive stress $\left(\sigma_{3}\right.$, Fig. 1b; Delvaux and Barth, 2010; Ebinger et al., 2019; Williams et al., 2019). This $\sigma_{3}$ orientation is comparable to the $\sigma_{3}$ direction inferred from regional joint orientations (Williams et al., 2019) and the geodetically derived extension direction between the Nubia and Rovuma plates (Fig. 1b; Saria et al., 2014; Stamps et al., 2018, 2020).

Using instrumental catalogues, probabilistic seismic hazard analysis (PSHA) finds that there is a $10 \%$ probability of exceeding $0.15 \mathrm{~g}$ peak ground acceleration in the next 50 years in southern Malawi (Midzi et al., 1999; Poggi et al., 2017). Through the SMAFD and SMSSD, we outline how geological and geodetic data can be collated and assessed so that they may also be incorporated into PSHA in southern Malawi.

\section{Mapping and describing active faults in the South Malawi Active Fault Database (SMAFD)}

An active fault database consists of an active fault map, where for each fault, attributes are added that detail geomorphic, kinematic, geometric, and geological information about the fault (Christophersen et al., 2015; Styron and Pagani, 2020). Typically, an active fault database is stored in a geographic information system (GIS) environment, in which the fault attributes are assigned to a linear feature that represents the fault's geomorphic trace (e.g. Langridge et al., 2016; Machette et al., 2004; Styron et al., 2020). In this section, we describe how active faults were mapped in the South Malawi Active Fault Database (SMAFD) as well as the geomorphic attributes that were assigned to them. Estimates of associated earthquake source parameters, which are collated separately in the South Malawi Seismogenic Source Database (SMSSD), are described in Sect. 4.

\subsection{Identifying active and inactive faults in southern Malawi}

There are many inherent limitations in mapping active faults. Even in countries with well-developed databases, such as Italy and New Zealand, their success in accurately predicting the locations of future surface-rupturing earthquakes is, at best, mixed (Basili et al., 2008; Nicol et al., 2016a). An active fault might not be recognised because evidence of previous surface rupture is subsequently buried, eroded (Wallace, 1980), or the fault itself is blind (e.g. Quigley et al., 2012), which in turn depends on earthquake magnitude, focal depth, thickness of the seismogenic crust, and the local geology. 
Furthermore, although active and inactive faults are typically differentiated by the age of the most recent earthquake, the precise maximum age that is used to define "active" varies between different active fault databases depending on the regional strain rate (i.e. plate boundary vs. stable craton) and the prevalence of youthful sediments (Clark et al., 2012; Jomard et al., 2017; Langridge et al., 2016; Machette et al., 2004). Indeed, it may not always be possible to reliably determine if an exposed fault has been recently active or not (Cox et al., 2012; Nicol et al., 2016a).

Each of these issues has relevance to mapping active faults in southern Malawi. Firstly, active faults may be buried by sediments deposited due to tectonic subsidence (Gawthorpe and Leeder, 2000) and/or by regular (10-100 ka) climate-driven $\sim 100 \mathrm{~m}$ scale fluctuations in the level of Lake Malawi, which would likely flood the Zomba and Makanjira basins (Ivory et al., 2016; Lyons et al., 2015; Wedmore et al., 2020a). Alternatively, the relatively thick (30$35 \mathrm{~km})$ seismogenic crust in southern Malawi means that even moderate-large earthquakes $\left(M_{\mathrm{W}}>6\right)$ do not necessarily result in surface rupture, as illustrated by the $M_{\mathrm{W}} 6.3$ Salima earthquake (Gupta, 1992; Jackson and Blenkinsop, 1993). Finally, except for studies around Lake Malombe (Van Bocxlaer et al., 2012), there is no chronostratigraphic control for this section of the EARS to help differentiate between inactive and active faults (Dulanya, 2017; Wedmore et al., 2020a).

Thus, for the SMAFD, we define active faults based on evidence of activity within the current tectonic regime. Such an approach has been advocated elsewhere in the EARS (Delvaux et al., 2017) and in other areas with low levels of seismicity, few paleoseismic studies, and/or where there are faults that are favourably oriented for failure in the current stress regime but that have no definitive evidence of recent activity (Nicol et al., 2016a; De Pascale et al., 2017; Villamor et al., 2018). In practice, this means that faults will be included in the SMAFD if they can be demonstrated to have been active during East African rifting. This evidence can vary from the accumulation of post-Miocene hanging-wall sediments to the presence of a steep fault scarp, offset alluvial fans, and/or knickpoints in rivers that have migrated only a short vertical distance $(<100 \mathrm{~m})$ upstream (Hodge et al., 2019, 2020; Jackson and Blenkinsop, 1997; Wedmore et al., 2020a). We note that the absence of post-Miocene sediments in the hanging wall of a normal fault does not necessarily imply that it is inactive, if, for example, faults are closely spaced across strike so that sediments are eroded during subsequent footwall uplift of an interior normal fault (e.g. ChirobweNcheu Fault, Fig. 3c; see also Mortimer et al., 2016; Muirhead et al., 2016). In these cases, if there is other evidence of recent activity (e.g. scarp, triangular facets), these faults are still included.

For the sake of completeness, major faults that control modern-day topography but that do not fit the criteria of being active (e.g. Karoo faults) were mapped separately
(Fig. 2a). However, this map is not necessarily complete for all other faults in southern Malawi, and we also cannot definitively exclude the possibility that some of these faults are still active although they display no evidence for it. The relatively broad definition of an active fault may also mean that some inactive faults are included in the SMAFD. However, in applying the opposite approach (i.e. requiring an absolute age for the most recent activity on a fault) there is a greater risk that faults mistakenly interpreted to be inactive subsequently rupture in a future earthquake (Litchfield et al., 2018; Nicol et al., 2016a).

\subsection{Datasets for mapping faults in southern Malawi}

\subsubsection{Legacy geological maps}

Between the 1950s and 1970s, the geology of southern Malawi was systematically mapped at a $1: 100000$ scale. These studies noted evidence of recent displacement on the Thyolo (Habgood et al., 1973), Bilila-Mtakataka, Tsikulamowa (Walshaw, 1965), and Mankanjira faults (King and Dawson, 1976). However, they did not systematically distinguish between active and inactive faults. Furthermore, these studies are in places ambiguous with equivalent structures in the Zomba Graben being variably described as "terrace features" (Bloomfield, 1965), active fault scarps (Dixey, 1926), and Late Jurassic-Early Cretaceous faults (Dixey, 1938).

\subsubsection{Geophysical datasets}

Regional-scale aeromagnetic data were acquired across Malawi in 2013 by the Geological Survey Department of Malawi (Fig. 2c; Kolawole et al., 2018a; Laõ-Dávila et al., 2015). These survey data were used to refine fault mapping in cases where features interpreted as faults in the aeromagnetic survey extended beyond their surface expression. Gravity surveys have also been used to map blind faults in the Lower Shire Basin (Chisenga et al., 2019), and these have been incorporated into the SMAFD.

\subsubsection{Digital elevation models}

The topography of southern Malawi is primarily controlled by EARS faulting (Dulanya, 2017; Laõ-Dávila et al., 2015; Wedmore et al., 2020a) except in the case of the Kirk Range (Fig. 2b) as well as readily identifiable igneous intrusions and Karoo faults (Figs. 3c, 4b). To exploit this interaction between topography and active faulting, TanDEM-X digital elevation models (DEMs) with a $12.5 \mathrm{~m}$ horizontal resolution and an absolute vertical mean error of $\pm 0.2 \mathrm{~m}$ (Wessel et al., 2018) were acquired for southern Malawi (Fig. 2b). This small error means that the TanDEM-X data perform better at identifying the metre-scale scarps common in southern Malawi (Hodge et al., 2019; Wedmore et al., 2020a) than the more widely used but lower-resolution Shuttle Radar Topography Mission (SRTM) $30 \mathrm{~m}$ DEMs (Sandwell et al., 

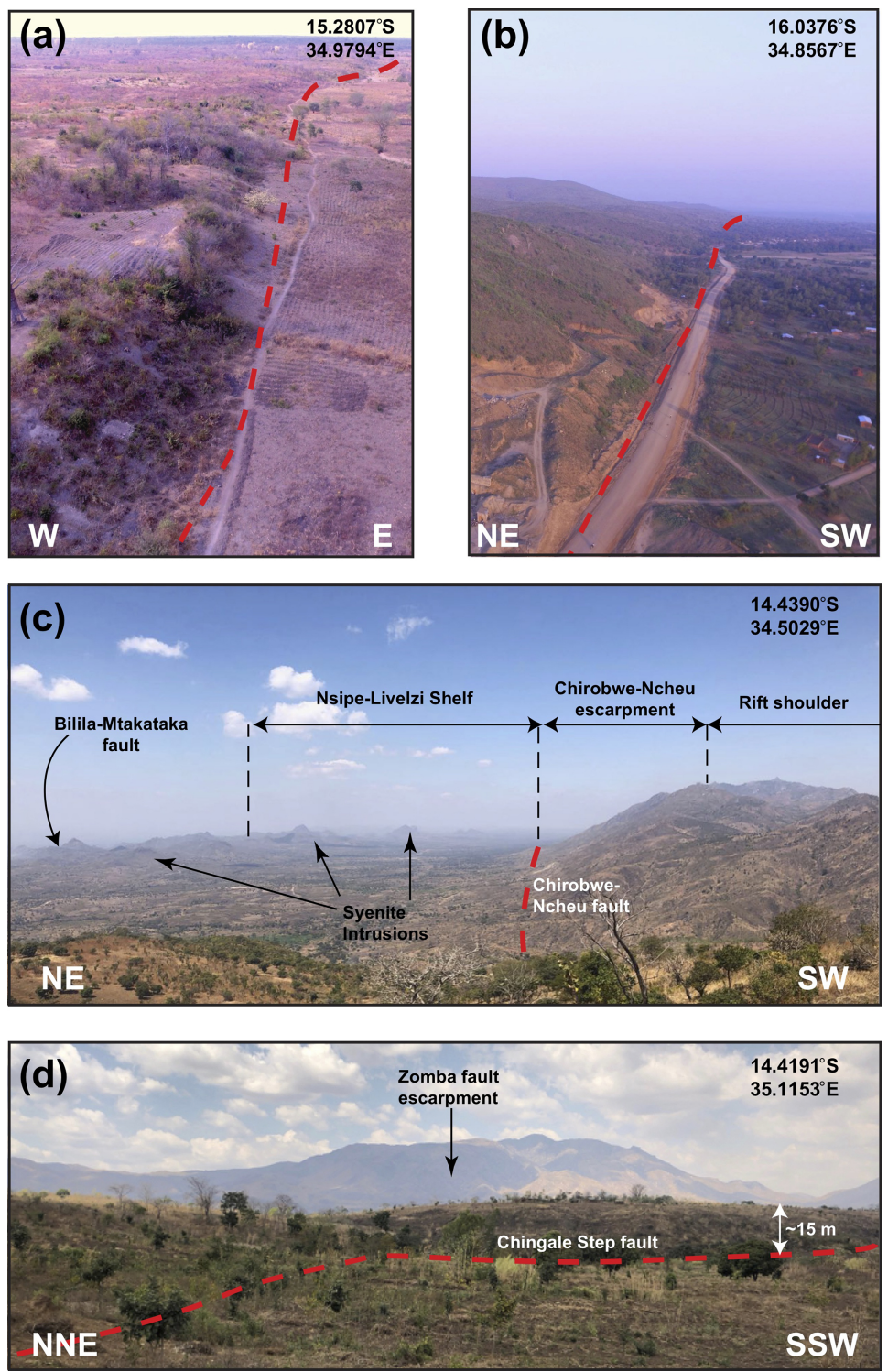

Figure 3. Field examples of border and intra-basin faults in southern Malawi. Unmanned aerial vehicle (UAV) images of scarps (dashed red line) along the (a) intra-basin Mlungusi Fault in the Zomba Graben as well as (b) the Thyolo Fault - the border fault for the Lower Shire Basin. (c) View across the western edge of the Makanjira Graben showing the Chirobwe-Ncheu and Bilila-Mtakataka faults as well as Proterozoic syenite intrusions (Walshaw, 1965). (d) Minor step in the scarp along the intra-basin Chingale Step fault, with the escarpment of the Zomba border fault behind.

2011). Furthermore, TanDEM-X data can be used to assess variations in along-strike scarp height (Hodge et al., 2018a, 2019; Wedmore et al., 2020a, b) and the interactions between footwall uplift and fluvial incision (Fig. 4a; Wedmore et al., 2020a). The Mwanza and Nsanje faults partly extended out of the region of TanDEM-X coverage, and these sections were mapped using the SRTM $30 \mathrm{~m}$ resolution DEM (Fig. 2b).

\subsubsection{Fieldwork}

To corroborate evidence of recent faulting recognised in DEMs and geological reports, fieldwork was conducted on several faults (Fig. 2b). This ranged from documenting features indicative of recent displacement on the faults, such as scarps, triangular facets, and displaced Quaternary-recent sediments, to comprehensively sampling the fault and surveying it with an unmanned aerial vehicle (Fig. 3; see also: Hodge et al., 2018a; Wedmore et al., 2020a, b; Williams et al., 2019). 


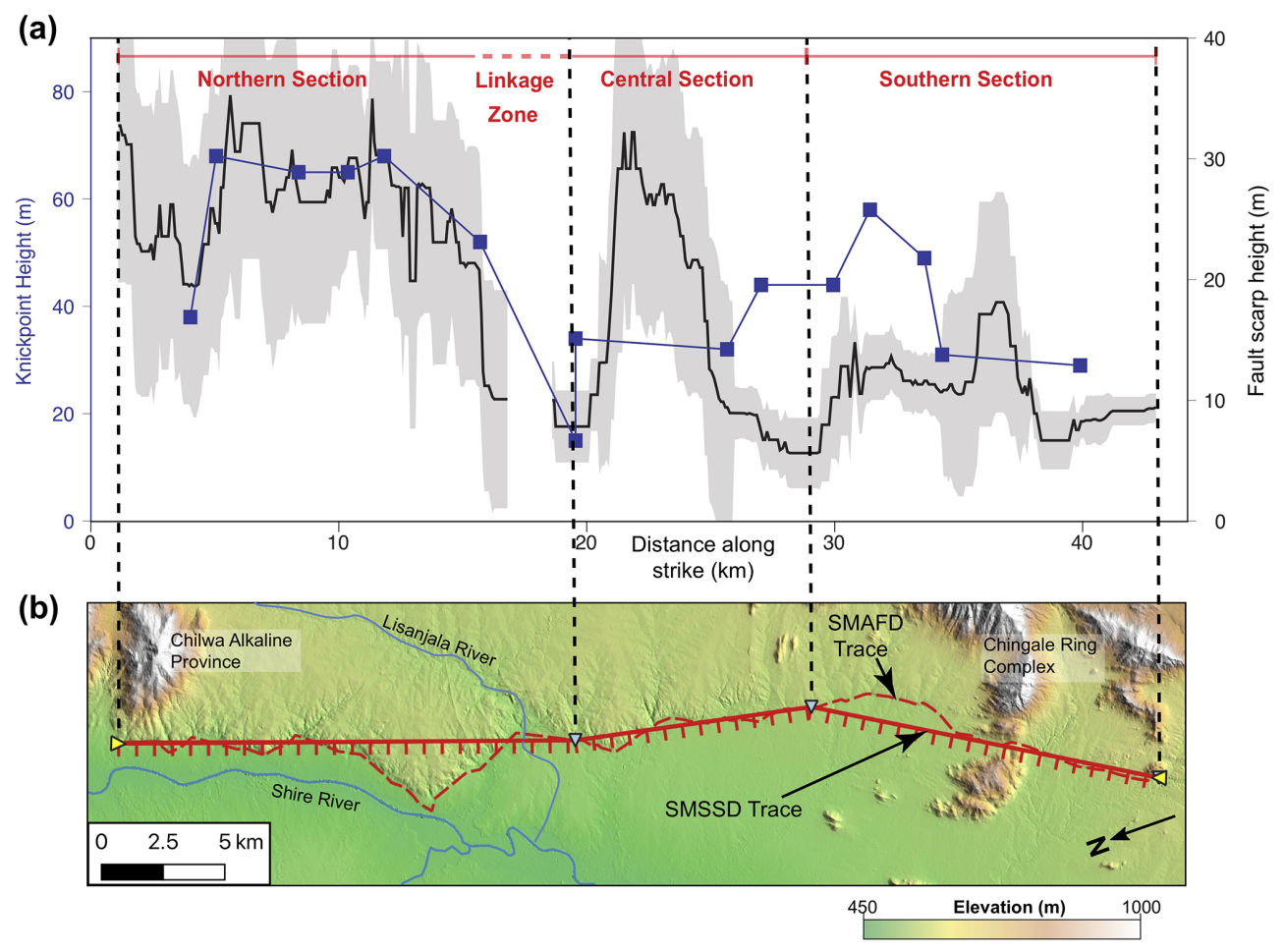

Figure 4. Fault segmentation along the Chingale Step fault, modified after Wedmore et al. (2020a). (a) Along-strike variation in stream knickpoint (blue points) and fault scarp height (black line), with the gap due to erosion by the Lisanjala River. Grey shading represents 1 standard deviation error in scarp height measurements (Wedmore et al., 2020a). (b) A map of the Chingale Step fault underlain by TanDEMX DEM, with the extent of the area shown in Fig. 2b. The dashed red line shows the surface trace of the fault as per the South Malawi Active Fault Database (SMAFD). The solid red line shows the simplified geometry of the fault in the South Malawi Seismogenic Source Database (SMSSD), where it is defined by straight lines between section end points (blue triangles). Ticks indicate fault hanging wall. An along-strike scarp height minima at the boundary between the northern and central section occurs at a bend in the fault scarp; however, there is no obvious geometrical complexity at the along-strike scarp height minima between the southern and central sections. Topography associated with the Proterozoic Chingale Ring Structure and Chilwa Alkaline Province (Bloomfield, 1965; Manda et al., 2019) is also indicated. For full details on panel (a), see Wedmore et al. (2020a).

\subsection{Strategy for mapping and describing active faults in the SMAFD}

Following the active fault definition and synthesis of the datasets described above, faults in southern Malawi are mapped following the approach outlined for the Global Earthquake Model Global Active Fault Database (GAF-DB) where each fault constitutes a single continuous GIS feature (Styron and Pagani, 2020). Therefore, the SMAFD differs from other active fault databases where each distinct geomorphic (i.e. traces) or geometric (i.e. sections) part of a fault is mapped as a separate GIS feature (Christophersen et al., 2015; Machette et al., 2004).

The attributes associated with each fault in the SMAFD are listed and briefly described in Table 1 . These resemble the attributes in the GEM GAF-DB that describe a fault's geomorphic attributes and confidence that it is still active (Styron and Pagani, 2020). To incorporate the multidisciplinary approach that we have used to map faults in southern Malawi, we also include a "Location method" attribute, which details how the fault was mapped (Table 1). Some fault attributes used in the GEM GAF-DB, such as slip rates, are not included in the SMAFD, as these data have not been collected in southern Malawi. We instead derive these attributes as outlined in Sect. 4 and incorporate them separately into the SMSSD (Table 2). However, within each database, a numerical ID system is used make the two databases compatible (Tables 1,2).

\section{A systems-based approach to estimating seismic source parameters: application to southern Malawi}

Typically, estimates of fault slip rate, earthquake magnitudes, and recurrence intervals are derived from paleoseismology, geodesy, historical records of past earthquakes, or considerations of the seismic moment rate (Basili et al., 2008; Field et al., 2014; Langridge et al., 2016; McCalpin, 2009; Molnar, 1979; Youngs and Coppersmith, 1985). However, as noted in Sect. 1, these types of data have not been collected in southern Malawi. Indeed, very few such records currently 
Table 1. List and brief description of attributes in the SMAFD. Attributes are based on the Global Earthquake Model Global Active Faults Database (Styron and Pagani, 2020).

\begin{tabular}{|c|c|c|c|}
\hline Attribute & Type & Description & Notes \\
\hline SMAFD-ID & Numeric, assigned & $\begin{array}{l}\text { Unique two-digit numerical } \\
\text { reference ID for each trace }\end{array}$ & \\
\hline Name & Text & & $\begin{array}{l}\text { Assigned based on previous } \\
\text { mapping or local geographic } \\
\text { feature. }\end{array}$ \\
\hline Geomorphic expression & Text & $\begin{array}{l}\text { Geomorphological feature used } \\
\text { to identify and map fault trace. }\end{array}$ & $\begin{array}{l}\text { For example, scarp and escarp- } \\
\text { ment }\end{array}$ \\
\hline Location method & Text & Dataset used to map trace. & $\begin{array}{l}\text { For example, type of digital el- } \\
\text { evation } \\
\text { model }\end{array}$ \\
\hline Accuracy & Numeric, assigned & $\begin{array}{l}\text { Coarsest scale at which trace } \\
\text { can be mapped; expressed as } \\
\text { denominator of map scale. }\end{array}$ & $\begin{array}{l}\text { Reflects the prominence of the } \\
\text { fault's geomorphic expression. }\end{array}$ \\
\hline activity_confidence & Numeric, assigned & $\begin{array}{l}\text { Certainty of neotectonic } \\
\text { activity }\end{array}$ & 1 if certain, 2 if uncertain \\
\hline exposure_quality & Numeric, assigned & Fault exposure quality & 1 if high, 2 if low \\
\hline epistemic_quality & Numeric, assigned & Certainty that fault exists there & 1 if high, 2 if low \\
\hline last_movement & Text & & $\begin{array}{l}\text { Currently this is unknown for } \\
\text { all faults in southern Malawi } \\
\text { but can be updated when new } \\
\text { information becomes available. }\end{array}$ \\
\hline References & Text & $\begin{array}{l}\text { Relevant geological maps/ } \\
\text { literature where fault has } \\
\text { been previously described. }\end{array}$ & \\
\hline SMSSD ID & Numeric, assigned & $\begin{array}{l}\text { ID of equivalent structure in } \\
\text { South Malawi Seismogenic } \\
\text { Source Database }\end{array}$ & $\begin{array}{l}\text { Will be multiple IDs for multi- } \\
\text { segment faults, as these consist } \\
\text { of multiple potential earthquake } \\
\text { sources }\end{array}$ \\
\hline
\end{tabular}

exist across the entire EARS (Delvaux et al., 2017; Muirhead et al., 2016; Siegburg et al., 2020; Zielke and Strecker, 2009), and even in regions with well-developed active fault databases, such as California and New Zealand, only a small number of faults have directly measured slip rates and paleoseismic information (Field et al., 2014; Langridge et al., 2016).

In the absence of direct on-fault slip rate estimates, we suggest that they can be estimated through a systems-level approach in which geodetically derived plate motion rates are partitioned across faults in a manner consistent with their geomorphology and regional tectonic regime. Although such an approach has been used before over small regions (Cox et al., 2012; Litchfield et al., 2014), it has not been applied to an entire fault system. In addition, we outline how the uncertainties and alternative hypotheses that are inherent to this approach can, in common with seismic hazard practice elsewhere, be explored with a logic tree approach (Fig. 6; Field et al., 2014; Vallage and Bollinger, 2019; Villamor et al., 2018). We use the South Malawi Seismogenic Source Database (SMSSD) as an example of how this approach can be applied to narrow $(<100 \mathrm{~km}$ width; Buck, 1991) amagmatic continental rifts, where the distribution of regional strain between border faults and intra-basin faults is well constrained by previous studies (Agostini et al., 2011a; Corti, 2012; Gupta et al., 1998; Morley, 1988; Muirhead et al., 2016, 2019; Nicol et al., 1997; Shillington et al., 2020; Wedmore et al., 2020a; Wright et al., 2020).

\subsection{Earthquake source geometry}

Faults may rupture both along their entire length and in smaller individual-section ruptures that are often bounded by changes in fault geometry (DuRoss et al., 2016; Goda et al., 2018; Gómez-Vasconcelos et al., 2018; Hodge et al., 2015; 
Table 2. List and brief description of fault geometry, slip rate estimates, and earthquake source attributes in the SMSSD.

\begin{tabular}{|c|c|c|c|}
\hline Attribute & Type & Description & Notes \\
\hline SMSSD-ID & $\begin{array}{l}\text { Numeric, } \\
\text { assigned }\end{array}$ & $\begin{array}{l}\text { Unique numerical reference ID for } \\
\text { each seismic source }\end{array}$ & \\
\hline Fault name & Text & Fault that section belongs to & $\begin{array}{l}\text { Assigned based on previous mapping or local } \\
\text { geographic feature. }\end{array}$ \\
\hline Section name & Text & & $\begin{array}{l}\text { Assigned based on previous mapping, local } \\
\text { geographic feature, or location along fault. }\end{array}$ \\
\hline Basin & Text & Basin that fault is located within. & Used in slip rate calculations. \\
\hline Fault type & Text & Intra-basin or border fault & \\
\hline $\begin{array}{l}\text { Section length } \\
\left(L_{\mathrm{sec}}\right)\end{array}$ & $\begin{array}{l}\text { Numeric, } \\
\text { assigned }\end{array}$ & $\begin{array}{l}\text { Straight-line distance between } \\
\text { section tips. }\end{array}$ & $\begin{array}{l}\text { Measured in kilometres. Except for linking sec- } \\
\text { tions, must be }>5 \mathrm{~km} \text {. }\end{array}$ \\
\hline Section strike & $\begin{array}{l}\text { Numeric, } \\
\text { assigned }\end{array}$ & $\begin{array}{l}\text { Measured from section tips, using } \\
\text { bearing that is }<180^{\circ} \text {. }\end{array}$ & \\
\hline $\begin{array}{l}\text { Fault length } \\
\left(L_{\text {fault }}\right)\end{array}$ & $\begin{array}{l}\text { Numeric, } \\
\text { assigned }\end{array}$ & $\begin{array}{l}\text { Straight-line distance between fault } \\
\text { tips or sum of } L_{\mathrm{sec}} \text { for segmented faults. }\end{array}$ & Measured in kilometres. \\
\hline Fault strike & $\begin{array}{l}\text { Numeric, } \\
\text { assigned }\end{array}$ & $\begin{array}{l}\text { Measured from fault tips using } \\
\text { bearing }<180^{\circ} \text {. }\end{array}$ & $\begin{array}{l}\text { For segmented (i.e. non-planar) this is an "aver- } \\
\text { aged" value of fault geometry, which is required } \\
\text { for slip rate estimates (Eq. } 3 \text { ). }\end{array}$ \\
\hline $\operatorname{Dip}(\delta)$ & $\begin{array}{l}\text { Numeric, } \\
\text { assigned }\end{array}$ & & $\begin{array}{l}\text { Attribute parameterised by a set of representa- } \\
\text { tive values }\left(40,53,65^{\circ}\right) \text {. }\end{array}$ \\
\hline Dip direction & Text & Compass quadrant that fault dips in. & \\
\hline Fault width $(W)$ & $\begin{array}{l}\text { Numeric, } \\
\text { calculated }\end{array}$ & $\begin{array}{l}\text { Calculated from Eq. (2) from } \\
\text { Leonard (2010) scaling } \\
\text { relationship using } L_{\text {fault }} \text {. }\end{array}$ & $\begin{array}{l}\text { Not equivalent to rupture width for individual- } \\
\text { section earthquakes. }\end{array}$ \\
\hline Slip type & Text & Fault kinematics & All faults in the SMSSD assumed to be normal \\
\hline $\begin{array}{l}\text { Section net slip } \\
\text { rate }\end{array}$ & $\begin{array}{l}\text { Numeric, } \\
\text { calculated }\end{array}$ & Calculated from Eq. (3). & $\begin{array}{l}\text { In millimetres per year. All faults in the SMSSD } \\
\text { assumed to be normal, so is equivalent to dip- } \\
\text { slip rate. }\end{array}$ \\
\hline Fault net slip rate & $\begin{array}{l}\text { Numeric, } \\
\text { calculated }\end{array}$ & Calculated from Eq. (3). & $\begin{array}{l}\text { In millimetres per year. All faults in the SMSSD } \\
\text { assumed to be normal, so is equivalent to dip- } \\
\text { slip rate. Different from section net slip rate } \\
\text { where fault strike } \neq \text { section strike. }\end{array}$ \\
\hline $\begin{array}{l}\text { Section earthquake } \\
\text { magnitude }\end{array}$ & $\begin{array}{l}\text { Numeric, } \\
\text { calculated }\end{array}$ & $\begin{array}{l}\text { Calculated from Leonard (2010) scaling } \\
\text { relationship using Eq. (4) and } L_{\mathrm{sec}} \text {. }\end{array}$ & $\begin{array}{l}\text { Lower, intermediate, and upper values } \\
\text { calculated. }\end{array}$ \\
\hline $\begin{array}{l}\text { Fault earthquake } \\
\text { magnitude }\end{array}$ & $\begin{array}{l}\text { Numeric, } \\
\text { calculated }\end{array}$ & $\begin{array}{l}\text { Calculated from Leonard (2010) scaling } \\
\text { relationship using Eq. (4) and } L_{\text {fault }} \text {. }\end{array}$ & $\begin{array}{l}\text { Lower, intermediate, and upper values } \\
\text { calculated. }\end{array}$ \\
\hline $\begin{array}{l}\text { Section earthquake } \\
\text { recurrence interval }(R)\end{array}$ & $\begin{array}{l}\text { Numeric, } \\
\text { calculated }\end{array}$ & $\begin{array}{l}\text { Calculated from Eq. (6) and using } L_{\mathrm{sec}} \\
\text { to calculate average single-event } \\
\text { displacement in Eq. (5). }\end{array}$ & $\begin{array}{l}\text { Lower, intermediate, and upper values } \\
\text { calculated. }\end{array}$ \\
\hline $\begin{array}{l}\text { Fault earthquake } \\
\text { recurrence interval }(R)\end{array}$ & $\begin{array}{l}\text { Numeric, } \\
\text { calculated }\end{array}$ & $\begin{array}{l}\text { Calculated from Eq. (6) and using } L_{\text {fault }} \\
\text { to calculate average single-event } \\
\text { displacement in Eq. (5). }\end{array}$ & $\begin{array}{l}\text { Lower, intermediate, and upper values } \\
\text { calculated. }\end{array}$ \\
\hline Fault notes & Text & $\begin{array}{l}\text { Remaining miscellaneous information } \\
\text { about fault. }\end{array}$ & \\
\hline References & Text & $\begin{array}{l}\text { Relevant geological maps/literature } \\
\text { where fault has been } \\
\text { previously described. }\end{array}$ & \\
\hline SMAFD-ID & $\begin{array}{l}\text { Numeric, } \\
\text { assigned }\end{array}$ & $\begin{array}{l}\text { ID of equivalent structure in South } \\
\text { Malawi Active Fault Database }\end{array}$ & \\
\hline
\end{tabular}


Iezzi et al., 2019; Valentini et al., 2020). Therefore, the basic GIS feature in the SMSSD is a fault section, where individual faults from the SMAFD may be divided into multiple sections by bends in their fault trace (Fig. 2d; DuRoss et al., 2016; Jackson and White, 1989; Wesnousky, 2008; Zhang et al., 1991). Along-strike minima in fault displacement (e.g. scarp or knickpoint height) may also be indicative of segmentation (Willemse, 1997), but these do not always coincide with geometrical complexities in southern Malawi (Fig. 4; Hodge et al., 2018a, 2019; Wedmore et al., 2020a, b). This may indicate that deeper structures, not visible in the surficial fault geometry, are also influencing fault segmentation (Wedmore et al., 2020b). Therefore, where along-strike scarp height measurements exist, these local minima are also used to define fault sections (Figs. 2d, 4).

Faults that are closely spaced across strike but are not physically connected may also rupture together through "soft linkages" (Childs et al., 1995; Wesnousky, 2008; Willemse, 1997; Zhang et al., 1991). In the SMSSD, we follow empirical observations and Coulomb stress modelling that suggests that normal fault earthquakes may rupture across steps whose width is $<20 \%$ of the combined length of the interacting sections, up to a maximum separation of $10 \mathrm{~km}$ (Biasi and Wesnousky, 2016; Hodge et al., 2018b), and we use this as a criteria to assign whether two en echelon faults in the SMSSD may rupture together.

A number of geometrical attributes are then assigned to both individual sections and whole faults in the SMSSD (Table 2). Section length $\left(L_{\mathrm{sec}}\right)$ is defined as the straight-line distance between section end points (Fig. 4b). This approach avoids the difficulty of measuring the length of fractal features, and it accounts for the hypothesis that small-scale (less than kilometre-scale) variations in fault geometry in southern Malawi may represent only near-surface complexity (depths $<5 \mathrm{~km}$ ) and that the faults are relatively planar at depth (Hodge et al., 2018a). However, it only provides a minimum estimate of section length. For segmented faults in the SMSSD, fault length $\left(L_{\text {fault }}\right)$ is the sum of $L_{\mathrm{sec}}$, otherwise $L_{\text {fault }}$ is the distance between its tips (Fig. 4b). As each GIS feature in the SMSSD represents a distinct earthquake source, we consider that $L_{\mathrm{sec}}$ and/or $L_{\text {fault }}$ must be $>\sim 5 \mathrm{~km}$, except in the case of linking sections that rupture only in whole-fault ruptures. (Christophersen et al., 2015).

In southern Malawi, fault dip is either unknown or uncertain, because fault planes are rarely exposed, surface processes affect scarp angle (Hodge et al., 2020), and/or dip at depth is not constrained. This difficulty in measuring fault dip is common, and dip has been parameterised using a range of reasonable values in these cases (Christophersen et al., 2015; Langridge et al., 2016; Styron et al., 2020). Thus, we assign minimum, intermediate, and maximum dip values in the SMSSD of 40,53 , and $65^{\circ}$ respectively, which encapsulate dip estimates from field data in southern Malawi (Hodge et al., 2018a; Williams et al., 2019), and earthquake focal mechanisms (Biggs et al., 2010; Ebinger et al., 2019), seismic reflection data (Mortimer et al., 2007; Wheeler and Rosendahl, 1994), and aeromagnetic surveys (Kolawole et al., 2018a) elsewhere in Malawi.

It is typically assumed that fault width $(W)$ can be estimated by projecting the difference in lower and upper seismogenic depth into fault dip $(\delta)$, with the assumption that faults are equidimensional up to the point where $W$ is limited by the thickness of the seismogenic crust (Christophersen et al., 2015):

$W=\left\{\begin{array}{l}L_{\text {fault }}, \text { where } L_{\text {fault }} \leq \frac{z}{\sin \delta} ; \\ \frac{z}{\sin \delta}, \text { where } L_{\text {fault }}>\frac{z}{\sin \delta}\end{array}\right.$

In southern Malawi, both seismogenic thickness, $z$ (30$35 \mathrm{~km}$; Jackson and Blenkinsop, 1993; Craig et al., 2011), and $\delta\left(40-65^{\circ}\right.$, as justified above) are poorly constrained, so a range of $W$ values must be considered. Furthermore, ruptures unlimited by $z$ are not necessarily equidimensional (Leonard, 2010; Wesnousky, 2008). Therefore, in the SMSSD, we estimate $W$ from an empirical scaling relationship between fault length and $W$ (Leonard, 2010):

$W=C_{1} L_{\text {fault }}^{\beta}$,

where $L_{\text {fault }}>5 \mathrm{~km}$, and $C_{1}$ and $\beta$ are empirically derived constants that are equal to 17.5 and 0.66 respectively for interplate dip-slip earthquakes (Leonard, 2010). As shown in Fig. 5c, when applying Eq. (2), estimates of $W$ in the SMSSD are consistent with (1) observations of $>1$ length-to-width ratios for dip-slip earthquakes (Fig. 5c) and (2) the thick seismogenic crust in East Africa (i.e. $W \sim 40 \mathrm{~km}$, Fig. 5 c; Craig et al., 2011; Ebinger et al., 2019; Jackson and Blenkinsop, 1993; Lavayssière et al., 2019; Nyblade and Langston, 1995).

\subsection{Estimating fault slip rates}

For a narrow amagmatic continental rift such as the EARS in southern Malawi, the first step to estimate slip rates is to divide the rift along its axis into its basins (Fig. 2b); within each basin, the mapped faults are then divided into border and intra-basin faults. We define border faults geometrically, as a fault located at the edge of the rift with the implicit assumption that all other mapped active faults are intra-basin faults (Fig. 2d; Ebinger, 1989; Gawthorpe and Leeder, 2000; Muirhead et al., 2019; Wedmore et al., 2020b). These geometric definitions have no direct implications for how displacement is partitioned among border and intra-basin faults.

The slip rate for each fault or fault section $i$ is then estimated using the following equation:

Slip rate $(i)=\left\{\begin{array}{l}\frac{\alpha_{\mathrm{bf}} v \cos (\theta(i)-\phi)}{n_{\mathrm{f}} \cos \delta}, \text { for border faults } \\ \frac{\left.\alpha_{\mathrm{if}} \mathrm{cos}(\theta)-\phi\right)}{n_{\mathrm{if}} \cos \delta}, \text { for intra-basin faults }\end{array}\right.$

Here, $\theta(i)$ is the fault or fault section slip azimuth, $v$ and $\varphi$ are the respective horizontal rift extension rate and azimuth, $\alpha$ is a weighting applied to each fault depending on whether 

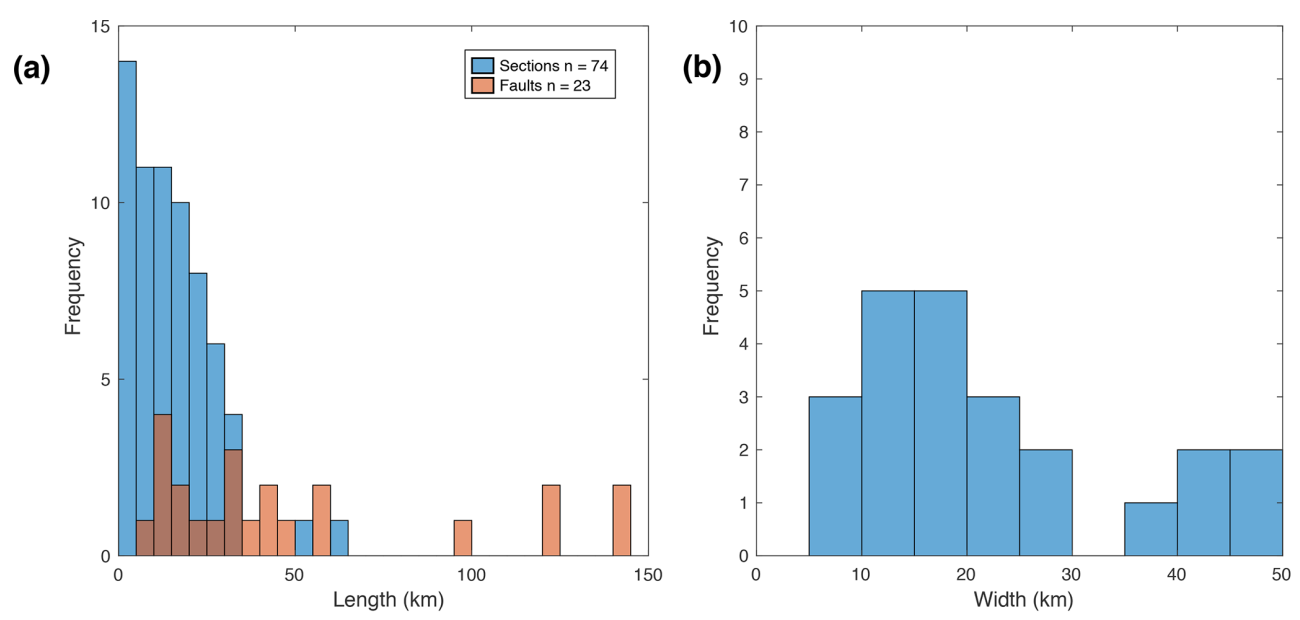

(c)

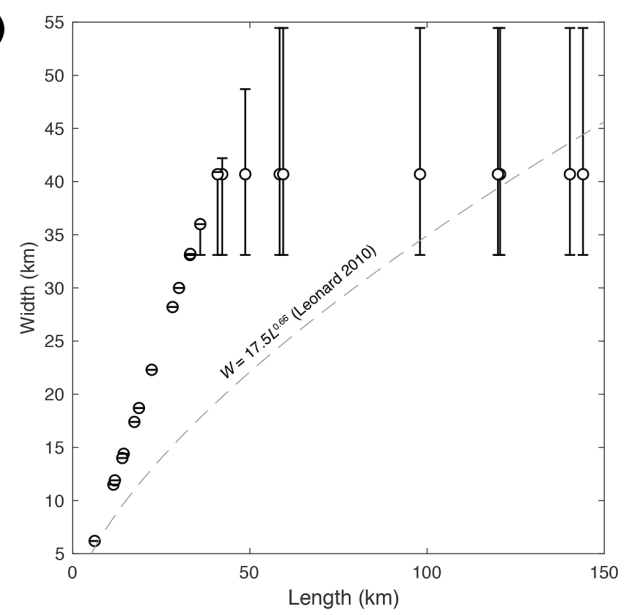

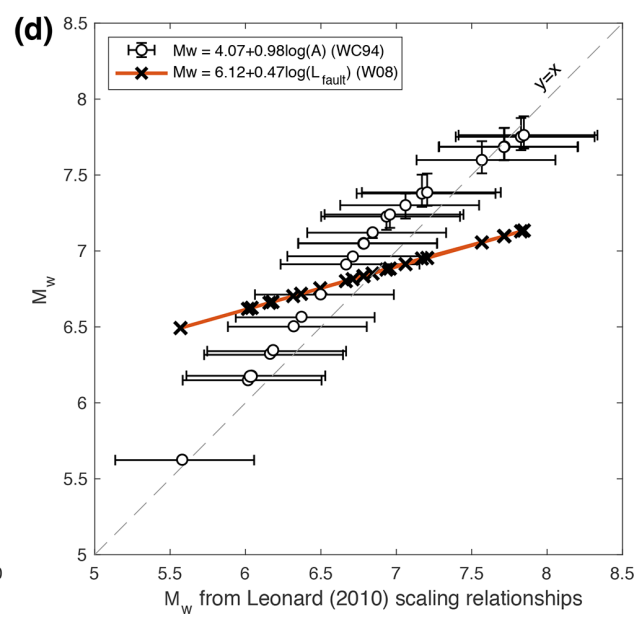

Figure 5. Assessment of fault geometry in the SMSSD. (a) Histograms showing the distribution of (a) fault $\left(L_{\text {fault }}\right)$ and section $\left(L_{\mathrm{sec}}\right)$ lengths in the SMSSD. (b) Histogram of fault widths in the SMSSD as derived from the Leonard (2010) scaling relationship (Eq. 2); in panel (c), the predicted aspect ratio of faults following this relationship (dashed grey line) in comparison to an alternative method to estimate $W$ using Eq. (1) (white circles). (d) A comparison of empirical scaling relationships used to estimate earthquake magnitudes $\left(M_{\mathrm{W}}\right)$ from fault geometry in the SMSSD. Leonard (2010) magnitudes estimated using Eq. (4), with error bars representing range of $C_{1}$ and $C_{2}$ values derived for interplate dip-slip faults. $A$ is the fault area calculated from $L_{\text {fault }}$ and $W$ using Eq. (1), WC94 is from Wells and Coppersmith (1994), and W08 is from Wesnousky (2008).

it is a border $\left(\alpha_{\mathrm{bf}}\right)$ or intra-basin $\left(\alpha_{\mathrm{if}}\right)$ fault, and it is divided by the number of mapped border faults $\left(n_{\mathrm{bf}}\right)$ or intra-basin faults $\left(n_{\text {if }}\right)$ in each basin (Fig. 6). Although Eq. (3) is specific for rifts, it could be adapted in other tectonic settings where there is an a priori understanding of the rate and distribution of regional strain - for example, to distribute regional strain between the basal detachment and thrust ramps in a fold and thrust belt (Poblet and Lisle, 2011), to distribute regional strain between multiple subparallel faults in a strike-slip system, or to assess more complex strain partitioning between kinematically distinct fault populations in transtensional or transpressional systems (Braun and Beaumont, 1995).

The distribution of $v$ between border $\left(\alpha_{\mathrm{bf}}\right)$ and intra-basin faults $\left(\alpha_{\mathrm{if}}\right)$ in an amagmatic narrow rift depends on factors such as total rift extension (Ebinger, 2005; Muirhead et al., 2016, 2019), rift obliquity (Agostini et al., 2011b), hanging- wall flexure (Muirhead et al., 2016; Shillington et al., 2020), lower crustal rheology (Heimpel and Olson, 1996; Wedmore et al., 2020a), and whether border faults have attained their maximum theoretical displacement (Accardo et al., 2018; Olive et al., 2014; Scholz and Contreras, 1998). In some incipient rifts like southern Malawi, extensional strain is observed to be localised $(\sim 80 \%-90 \%)$ on its border faults (Muirhead et al., 2019; Wright et al., 2020). Furthermore, evidence from boreholes and topography indicates that border faults in southern Malawi have relatively small throws $(<1000 \mathrm{~m}$, Fig. S1), which combined with its thick seismogenic crust indicates that the flexural extensional strain on its intra-basin faults is likely to be negligible (Billings and Kattenhorn, 2005; Muirhead et al., 2016; Wedmore et al., 2020a). However, detailed analysis of fault scarp heights across the Zomba Graben indicates that $\sim 50 \%$ of exten- 


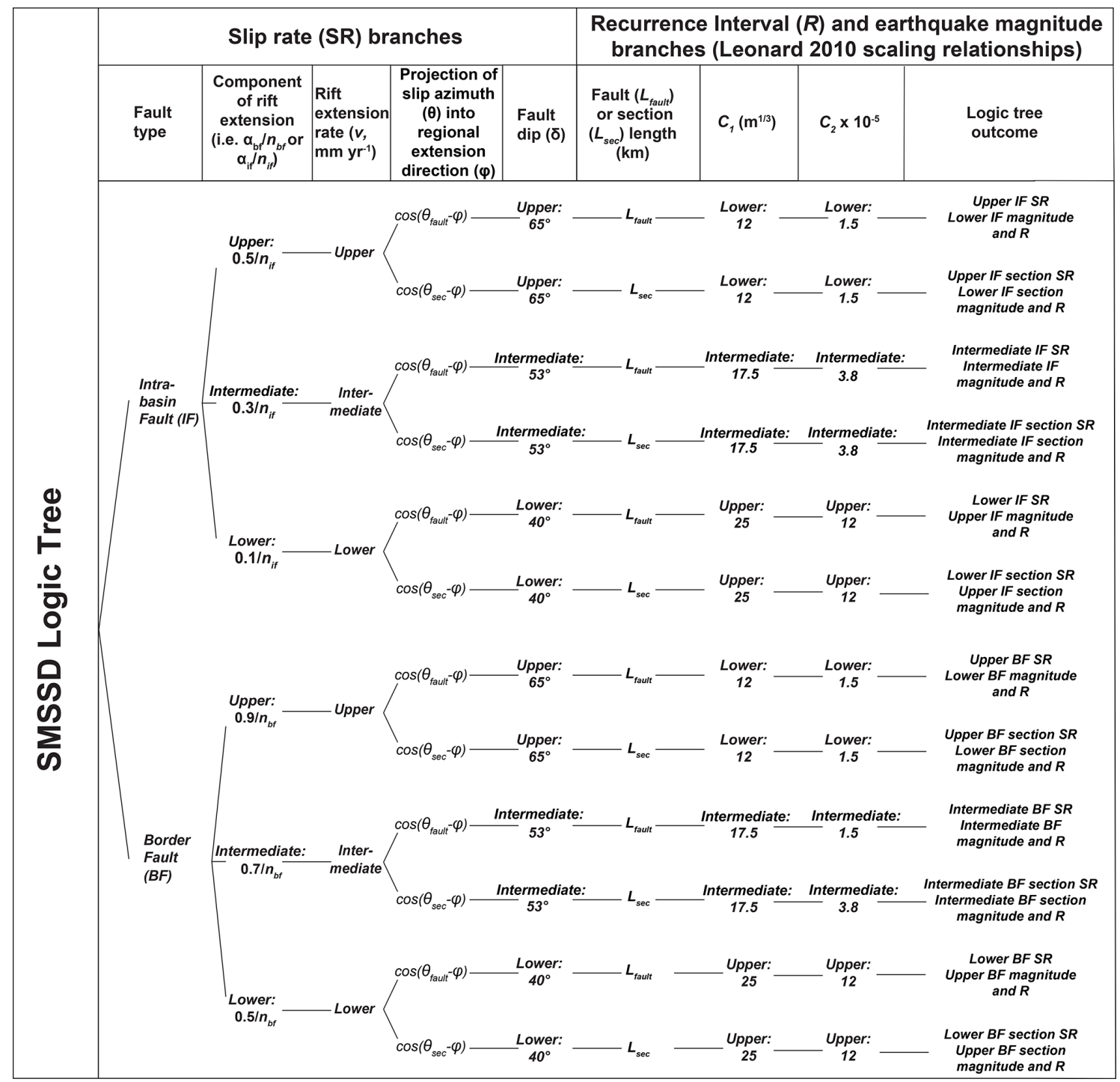

Figure 6. Logic tree for calculating lower, intermediate, and upper estimates of fault slip rates and earthquake magnitudes and recurrence intervals in the SMSSD; $\alpha_{\mathrm{bf}}$ and $\alpha_{\mathrm{if}}$ are the rift extension weighting assigned to border faults (BF) and intra-basin faults (IF) respectively; $n_{\mathrm{bf}}$ and $n_{\mathrm{if}}$ are the number of border or intra-basin faults in a basin respectively; and $\theta_{\text {fault }}$ and $\theta_{\text {sec }}$ are the respective whole-fault and individual-section slip azimuth values.

sional strain is currently distributed onto its intra-basin faults (Wedmore et al., 2020a). To account for this uncertainty in the SMSSD, lower, intermediate, and upper estimates of $\alpha_{\text {bf }}$ are set to 0.5, 0.7, and 0.9 respectively (Fig. 6). As $\alpha_{\mathrm{if}}=1-\alpha_{\mathrm{bf}}$, respective lower, intermediate, and upper estimates are 0.1, 0.3, and 0.5 (Fig. 6).

Where distinct intra-basin faults kinematically interact across steps, we consider these as one fault in Eq. (3), as this equation accounts for strain across, not along, the rift. For the Mwanza and Nsanje basins, no intra-basin faults are identified (Fig. 2b), so all the extension strain is assigned to their border faults (i.e. $\alpha_{\mathrm{bf}}=1$ ). In the case of the Nsanje Basin, however, this is extension is divided into increments of $30 \%$,
$50 \%$, and $70 \%$ between the Nsanje Fault and a border fault identified $25 \mathrm{~km}$ along strike in Mozambique (Fig. S1; Macgregor, 2015) to estimate its lower, intermediate, and upper slip rate.

In the SMSSD, the horizontal extension rate, $v$, is taken from the plate motion vector between the Rovuma and Nubia plates at the centre of each individual basin (Table 3, Figs. 1b, S1) using the Euler poles reported by Saria et al. (2013). We use the Euler pole (as defined by a location and rotation rate) and the uncertainties associated with the Euler pole (defined by an error ellipse; Fig. A1) to calculate the plate motion and the plate motion uncertainty between the Rovuma and Nubia plates for each basin (Table 3, Fig. 1b) following the methods 
Table 3. Coordinates from which the Nubia-Rovuma plate motion vector for different basins in southern Malawi was derived (Fig. 1b). The velocity, azimuth, and uncertainties of each vector are also reported given the Nubia-Rovuma Euler poles in Saria et al. (2013) (S13) or in Stamps et al. (2008) (S08; Fig. A1) and where the uncertainties associated with the Euler pole are derived from the methods presented in Robertson et al. (2016). For justification of basin centre locations, see Fig. S1.

\begin{tabular}{lrrrrr}
\hline Basin & $\begin{array}{r}\text { Centre of basin } \\
\text { latitude (S) }\end{array}$ & $\begin{array}{r}\text { Centre of basin } \\
\text { longitude (E) }\end{array}$ & $\begin{array}{l}\text { Geodetic } \\
\text { model }\end{array}$ & $\begin{array}{r}\text { Velocity and velocity } \\
\text { uncertainty of plate } \\
\text { motion (mm/yr) }\end{array}$ & $\begin{array}{r}\text { Azimuth, and azi- } \\
\text { muthal uncertainty } \\
\text { of plate motion }\end{array}$ \\
\hline Makanjira & 14.51 & 34.88 & $\mathrm{~S} 13$ & $1.08 \pm 1.66$ & $075^{\circ} \pm 089^{\circ}$ \\
& & & $\mathrm{S} 08$ & $3.01 \pm 0.28$ & $085^{\circ} \pm 002^{\circ}$ \\
\hline Zomba & 15.42 & 34.93 & $\mathrm{~S} 13$ & $0.88 \pm 1.65$ & $072^{\circ} \pm 110^{\circ}$ \\
& & & $\mathrm{S} 08$ & $2.84 \pm 0.28$ & $085^{\circ} \pm 002^{\circ}$ \\
\hline Lower Shire & 16.26 & 35.08 & $\mathrm{~S} 13$ & $0.69 \pm 1.65$ & $069^{\circ} \pm 141^{\circ}$ \\
& & & $\mathrm{S} 08$ & $2.69 \pm 0.28$ & $086^{\circ} \pm 002^{\circ}$ \\
\hline Nsanje & 17.28 & 35.23 & $\mathrm{~S} 13$ & $0.46 \pm 1.63$ & $063^{\circ} \pm 212^{\circ}$ \\
& & & $\mathrm{S} 08$ & $2.49 \pm 0.27$ & $086^{\circ} \pm 002^{\circ}$ \\
\hline Mwanza & $\mathrm{n} / \mathrm{a}$ & $\mathrm{n} / \mathrm{a}$ & $\mathrm{n} / \mathrm{a}$ & $0.6 \pm 0.4$ & $\mathrm{n} / \mathrm{a}$ \\
\hline
\end{tabular}

n/a: "not applicable".

outlined in Robertson et al. (2016). With this approach, the lower bound of $v$ is negative (i.e. the plate motion is contractional; Table 3). However, the topography and seismicity of southern Malawi clearly indicate that it is not a contractional regime nor is it a stable craton. Therefore, a lower bound of $0.2 \mathrm{~mm} / \mathrm{yr}$ horizontal extension is assigned in the SMSSD, which is considered the minimum strain accrual that is measurable using geodesy (Calais et al., 2016). There are no geodetic constraints for the extension rate across the Mwanza Basin as it lies along the poorly defined Angoni-San plate boundary (Daly et al., 2020). Therefore, we assign this basin an extension rate of $0.2-1 \mathrm{~mm} / \mathrm{yr}$. This reflects the smaller escarpment height along its border fault $(250 \mathrm{~m}$ vs. $\sim 750 \mathrm{~m}$; Fig. 2b) relative to the Lower Shire Basin, which indicates a slower average extension rate over geological time.

The rift extension azimuth $(\varphi)$ in southern Malawi is derived from a regional focal mechanism stress $\left(073^{\circ} \pm 012^{\circ}\right.$, Fig. 1b; Delvaux and Barth, 2010; Ebinger et al., 2019; Williams et al., 2019), as there is considerable uncertainty in this parameter from geodesy (Table 3; Saria et al., 2013). Faults in southern Malawi are considered to be normal (Delvaux and Barth, 2010; Hodge et al., 2015; Williams et al., 2019). Therefore, the slip azimuth $(\theta(i))$ is the dip direction of each fault or fault section, where it is then projected into $\varphi$ in Eq. (3). Although this sets up an apparent inconsistency in which variably striking faults accommodate normal dipslip under a uniform extension direction, this phenomena that can be explained by lateral heterogeneity in the lower crust in southern Malawi (Corti et al., 2013; Philippon et al., 2015; Wedmore et al., 2020a; Williams et al., 2019). To account for the uncertainty in $\varphi$, upper and lower extension rates are obtained by varying $\varphi \pm 012^{\circ}$ depending on the fault's dip direction (e.g. upper slip rate estimates for NE and NW dipping fault are estimated with $\varphi$ set to 061 and $085^{\circ}$ respectively). An example of these slip rate calculations for the central section of the Chingale Step fault is provided in Fig. 7.

\subsection{Earthquake magnitudes and recurrence intervals}

We estimate earthquake magnitudes in the SMSSD by applying empirically derived scaling relationships between fault length and earthquake magnitude. Scaling relationships between fault length and average single-event displacement $(\bar{D})$ can then be combined with slip rate estimates to calculate earthquake recurrence intervals $(R)$ through the relationship $R=\bar{D} /$ slip rate (Wallace, 1970). To select an appropriate set of earthquake-scaling relationships for the SMSSD, we consider three previously reported regressions and apply them to its mapped faults: (1) between normal fault length and $M_{\mathrm{W}}$ (Wesnousky, 2008), (2) interplate dipslip fault length and $M_{\mathrm{W}}$ (Leonard, 2010), and (3) fault area and $M_{\mathrm{W}}$ (Wells and Coppersmith, 1994) where $A$ is calculated using $W$ derived from Eq. (1).

We find that although generally comparable for $M_{\mathrm{W}}<7.5$, the Wells and Coppersmith (1994) regression overestimates magnitudes relative to Leonard (2010) (Fig. 5d). This likely reflects the discrepancy in $W$ between applying Eq. (1) and the Leonard (2010) regression (Eq. 2; Fig. 5c; Sect. 4.1). The Wesnousky (2008) regression overestimates magnitudes for $M_{\mathrm{W}}<6.9$ relative to Leonard (2010) equations and underestimates them at larger magnitudes (Fig. 5d). This may reflect that the Wesnousky (2008) regression is derived from only six events, and these events show a poor correlation between length and $M_{\mathrm{W}}$ (Pearson's regression coefficient $=0.36$ ). Given these considerations, the Leonard (2010) regressions are used in the SMSSD. Furthermore, these regressions are 
used to estimate $W$ (Sect. 4.1) and are self-consistent when estimating $M_{\mathrm{W}}$ and $\bar{D}$ from $L_{\text {fault }}$, which is not necessarily true for the other cases.

Thus, $M_{\mathrm{W}}$ and $\bar{D}$ are estimated in the SMSSD by

$$
\begin{aligned}
& M_{\mathrm{W}}(i)= \\
& \left\{\begin{array}{l}
\frac{\left(\frac{5}{2} \log L_{\mathrm{sec}}+\frac{3}{2} \log C_{1}+\log C_{2} \mu\right)-9.09}{1.5} \text { for individual-section ruptures and } \\
\frac{\left(\frac{5}{2} \log L_{\text {fault }}+\frac{3}{2} \log C_{1}+\log C_{2} \mu\right)-9.09}{1.5} \text { for whole-fault ruptures, and }
\end{array}\right.
\end{aligned}
$$

$\log \bar{D}(i)=$

$$
\left\{\begin{array}{l}
\frac{5}{6} \log L_{\mathrm{sec}}+\frac{1}{2} \log C_{1}+\log C_{2} \mu \text { for individual-section ruptures and } \\
\frac{5}{6} \log L_{\text {fault }}+\frac{1}{2} \log C_{1}+\log C_{2} \mu \text { for whole-fault ruptures, }
\end{array}\right.
$$

where $\mu$ is the shear modulus $\left(3.3 \times 10^{10} \mathrm{~Pa}\right), C_{1}$ is as defined for Eq. (2), and $C_{2}$ is another constant derived by Leonard (2010). Both constants are varied between the full range of values derived in a least square analysis (Leonard, 2010) to obtain lower, intermediate, and upper estimates of $M_{\mathrm{W}}$ and $\bar{D}$ (Figs. 6, 7). Following Eq. (5), recurrence intervals $R(i)$ can be calculated as follows:

$R(i)=\frac{\bar{D}(i)}{\operatorname{Slip} \operatorname{rate}(i)}$,

where upper estimates of $R$ are calculated by dividing the upper estimate of $\bar{D}$ by the lowest estimate of fault or section slip rate and vice versa (Fig. 6). An example of these earthquake source calculations for the central section of the Chingale Step fault is provided in Fig. 7.

\section{Key features of the SMAFD and SMSSD}

In this section, we briefly describe the fault mapping collated in the SMAFD and then the present fault slip rates, earthquake magnitudes, and recurrence intervals in the SMSSD as estimated by our systems-based approach.

\subsection{Border and intra-basin faults in southern Malawi}

The SMAFD contains 23 active faults across five EARS basins. The northernmost faults lie in the NW-SE trending Makanjira Graben, a full graben where two border faults, the Makanjira and Chirobwe-Ncheu, clearly define either side of the rift (Fig. 8a). Four intra-basin faults are identified, with, two of them, the Bilila-Mtakataka and Malombe faults, exhibiting steep scarps (Hodge et al., 2018a, 2019). In particular, one-dimensional diffusional models of scarp degradation suggest that the Bilila-Mtakataka Fault scarp formed within the past 10000 years (Hodge et al., 2020). The Malombe Fault forms a $\sim 500 \mathrm{~m}$ high escarpment that bounds the Shire Horst and divides post-Miocene deposits in the Makanjira Graben across strike (Fig. 8a; Hodge et al., 2019; Laõ-Dávila et al., 2015).

Along strike to the south, the NNE-SSW trending Zomba Graben contains a prominent border fault, the Zomba Fault, on its eastern edge, and three well-defined intra-basin fault scarps in its interior (Fig. 8b; Bloomfield, 1965; Wedmore et al., 2020a). The western edge of the Zomba Graben grades onto the Kirk Plateau where there are several deeply incised $\mathrm{N}-\mathrm{S}$ trending valleys that have been previously mapped as "rift valley faults" (Fig. 8b; Bloomfield and Garson, 1965). However, only one of these faults has an active scarp and accumulated post-Miocene sediments (the Lisungwe Fault; Wedmore et al., 2020a). In addition, the Wamkurumadzi Fault, which lies to the west of the Lisungwe, is also included in the SMAFD - albeit with low confidence - as evidence of recent activity is noted by Bloomfield and Garson (1965), and any recent sediments may have been eroded by the Wamkurumadzi River that flows along its base. Given the complex topography and ambiguity on fault activity, we tentatively interpret these faults as intra-basin faults in the SMSSD and note that the western Zomba Graben should be a priority area for future fault mapping.

The floor of the NW-SE trending Lower Shire Basin lies at an elevation $350 \mathrm{~m}$ lower than the floor of the Zomba Graben. Between these two EARS sections basement is exposed, and there is no evidence of tectonic activity that falls within the SMAFD definition of an active fault. Gravity surveys and topographic data indicate that the Lower Shire Basin exhibits a half-graben structure, with the Thyolo Fault bounding it to the northeast (Fig. 8d; Chisenga et al., 2019; Wedmore et al., 2020b). A number of intra-basin faults have been identified in the hanging wall of the Thyolo Fault (Chisenga et al., 2019), although none are identified in the Nsanje and Mwanza basins (Fig. 8d, e).

\subsection{Fault slip rates, and earthquake magnitudes and recurrence intervals in the SMSSD}

By implementing a logic tree approach to assess uncertainty in the SMSSD, three values (lower, intermediate, and upper) are derived for each calculated attribute (Table 2, Fig. 6). However, it is implicit that the upper and lower values have a low probability as they require a unique, and possibly unrealistic, combination of parameters. Therefore, we primarily report values obtained from applying the intermediate branches in the logic tree but discuss the uncertainties in Sect. 5.4.

Although the SMAFD contains 23 active faults, these are further subdivided into 74 sections in the SMSSD - of which 13 are linking sections. Section lengths $\left(L_{\mathrm{sec}}\right)$ range between 0.7 and $62 \mathrm{~km}$, whereas fault lengths ( $L_{\text {fault }}$ ) vary from 6.2 to $144 \mathrm{~km}$ (Fig. 5a, Table 4). The highest slip rates are estimated to be on the Thyolo and Zomba faults (intermediate estimates of $0.6-0.8 \mathrm{~mm} / \mathrm{yr}$ ). On intra-basin faults in the SMSSD, intermediate slip rate estimates are $0.05-0.1 \mathrm{~mm} / \mathrm{yr}$ (Fig. 9). Slip rates tend to be relatively fast in the Makanjira Graben (Fig. 9c), as the extension rate is higher (Table 3), and its NNW-SSE striking faults are more optimally oriented to the regional extension direction (Fig. 2). The difference between upper and lower slip rate estimates in the SMSSD logic tree is 


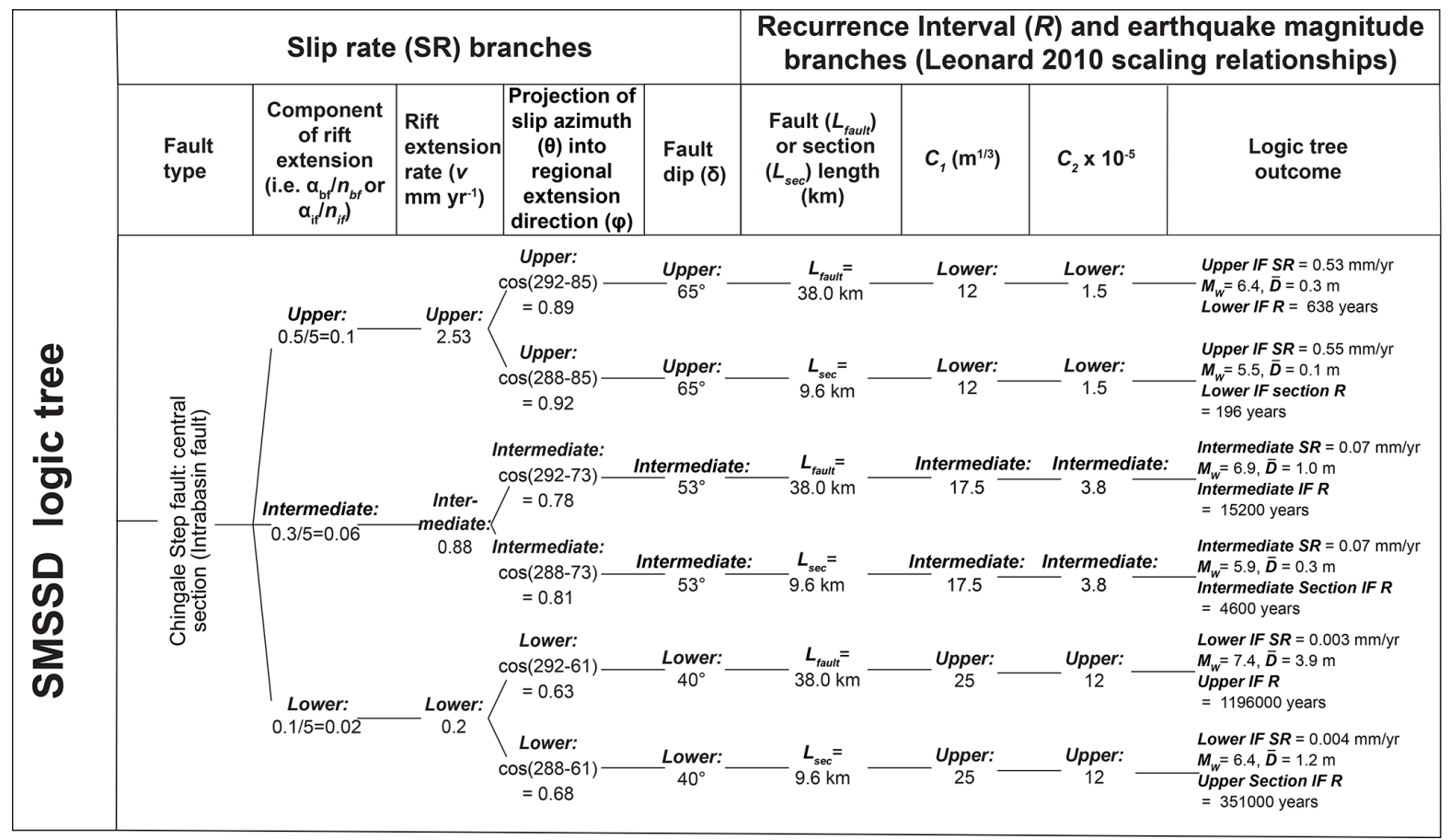

Figure 7. Example of the calculations in the SMSSD logic tree (Fig. 6), performed for the central section of the Chingale Step Fault (Fig. 4b). This is an intra-basin fault in the Zomba Graben, where the number of intra-basin faults $\left(n_{\text {if }}\right)$ is five. A multiparameter sensitivity analysis for these calculations is documented in Appendix A.

Table 4. Range of selected numeric attributes across all faults and sections in the SMSSD. To demonstrate how calculated attributes vary across different faults in the SMSSD, as opposed to variation from the set of parameters used to calculate them, the values shown are for the intermediate branches in the SMSSD logic tree (Fig. 6).

\begin{tabular}{lrrr}
\hline Attribute & Minimum & Median & Maximum \\
\hline Section length $\left(L_{\mathrm{sec}}, \mathrm{km}\right)$ & 0.7 & 13.4 & 62.4 \\
Fault length $\left(L_{\text {fault }}, \mathrm{km}\right)$ & 6.2 & 33.2 & 144.0 \\
Fault width $(W, \mathrm{~km})$ & 5.9 & 18.1 & 48.0 \\
Section net slip rate $(\mathrm{mm} / \mathrm{yr})$ & 0.05 & 0.13 & 0.90 \\
Fault net slip rate $(\mathrm{mm} / \mathrm{yr})$ & 0.05 & 0.08 & 0.81 \\
Section earthquake magnitude $\left(M_{\mathrm{W}}\right)$ & 5.4 & 6.3 & 7.2 \\
Fault earthquake magnitude $\left(M_{\mathrm{W}}\right)$ & 5.6 & 6.8 & 7.8 \\
Section earthquake recurrence interval $(R$, years $)$ & 380 & 2814 & 14600 \\
Fault earthquake recurrence interval $(R$, years $)$ & 2020 & 7870 & 23690 \\
\hline
\end{tabular}

2 orders of magnitude: $\sim 0.05-5 \mathrm{~mm} / \mathrm{yr}$ for the border faults and $\sim 0.005-0.5 \mathrm{~mm} / \mathrm{yr}$ on the intra-basin faults (Fig. 9).

For whole-fault ruptures along border faults, intermediate estimates of earthquake recurrence intervals $(R)$ are between 2000 and 5000 years, whereas they are between 10000 and 30000 years for intra-basin whole-fault ruptures (Fig. 10ac). Considerable uncertainty exists in these values, with the upper and lower estimates for $R$ varying from $10^{2}$ to $10^{5}$ years and from $\sim 10^{3}$ to $10^{6}$ years for border and intrabasin whole-fault ruptures respectively (Fig. 10a-c). Furthermore, if these faults rupture in individual sections, $R$ may be reduced by up to an order of magnitude (Fig. 10d-f). In- termediate estimates of earthquake magnitudes range from $M_{\mathrm{W}} 5.4$ to $M_{\mathrm{W}} 7.2$ for individual-section ruptures and from $M_{\mathrm{W}} 5.6$ to $M_{\mathrm{W}} 7.8$ for faults that rupture their entire length (Table 4, Fig. 11b). The SMSSD also includes one example where multiple en echelon faults, the Panga Fault system (Fig. 2d), could rupture together given the constraints outlined in Sect. 4.1.

\subsection{Robustness of fault slip rate estimates}

It is possible that slip rate estimates in the SMSSD are effectively upper bounds, as some proportion of the geodetically 

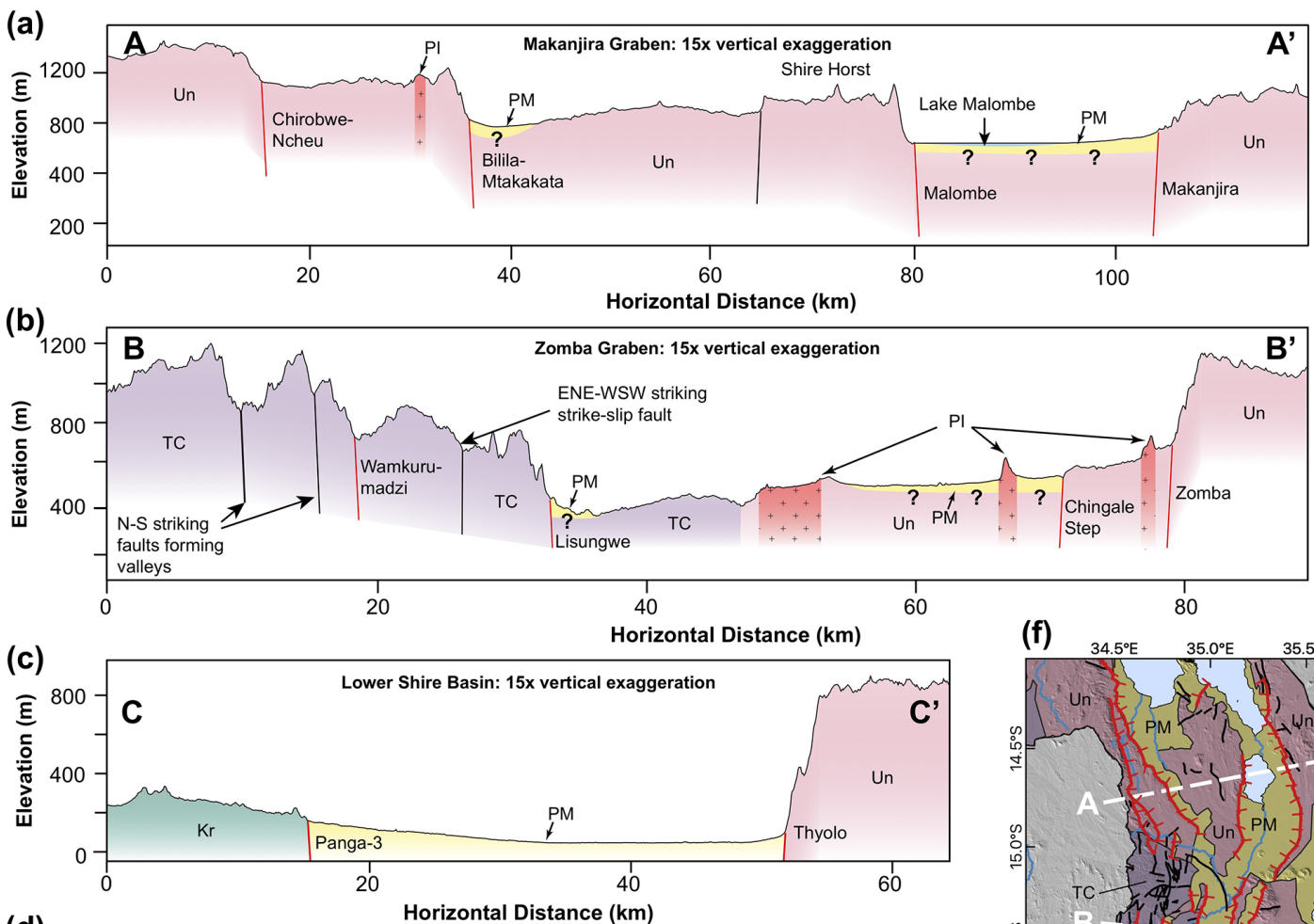

(d)
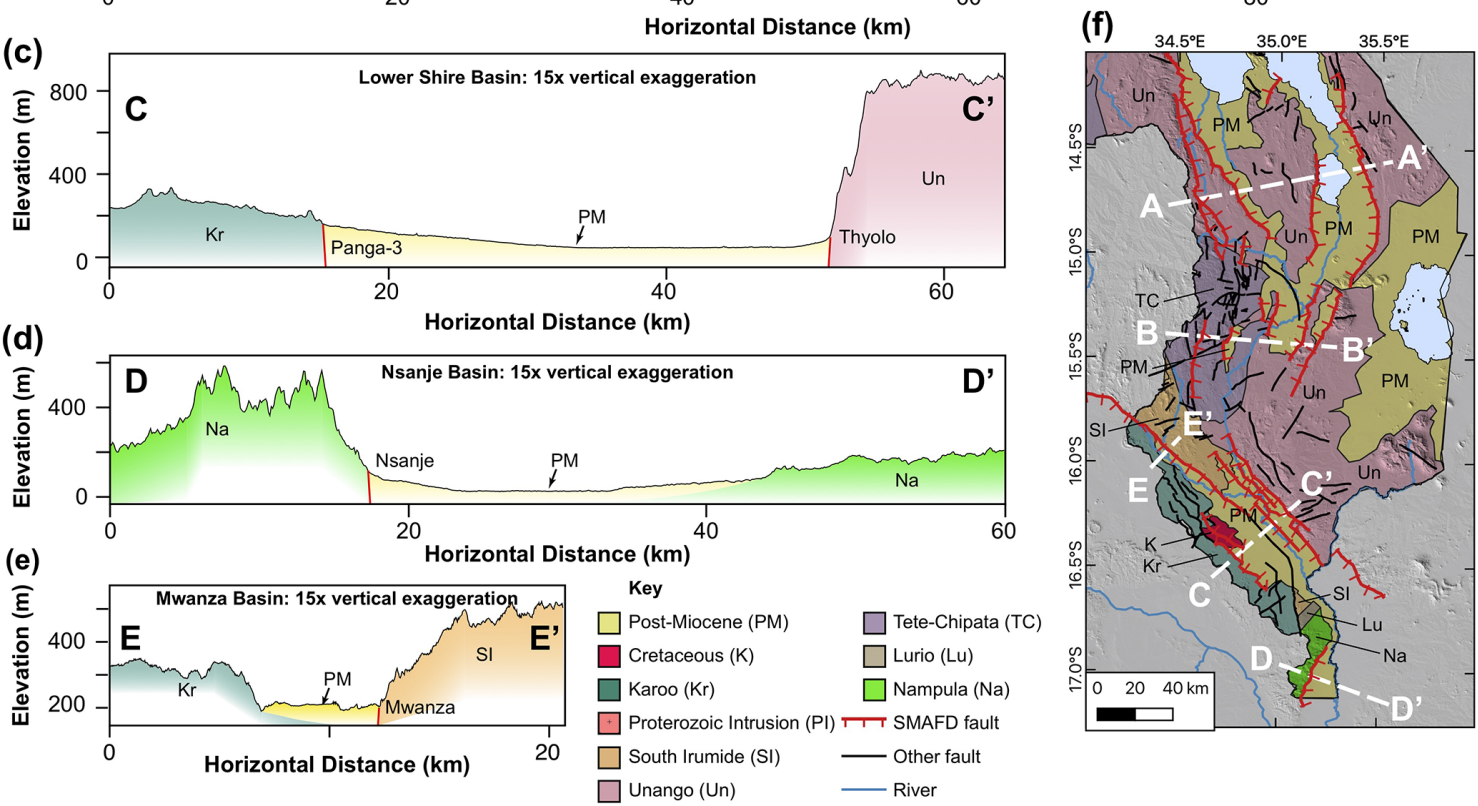

Figure 8. (a-e) Cross sections through each basin in southern Malawi. Topography from the TanDEM-X 12 m digital elevation model (DEM) except for panel (d) which is from the SRTM 30 m DEM. Tectonic terranes are from Fullgraf et al. (2017), except for Proterozoic intrusions (Bloomfield, 1965; Walshaw, 1965). All normal faults in cross sections inferred to dip at $60^{\circ}$. Post-Miocene deposits in panels (a) and (b) are shown to be 50-100 m thick, as estimated by borehole data (Fig. S1). (f) A simplified geological map for southern Malawi showing extent of cross sections that is underlain by the SRTM $30 \mathrm{~m}$ DEM.

derived rift extension may be accommodated by aseismic creep or along unrecognised faults. With regards to aseismic creep, the discrepancy between geodetic and seismic moment rates in Malawi implies that its faults are strongly coupled (Ebinger et al., 2019; Hodge et al., 2015). This is also consistent with the velocity-weakening behaviour of some samples from the rift in deformation experiments at lower crustal pressure-temperature conditions (Hellebrekers et al., 2019).

Conversely, the possible inclusion of inactive faults in the SMAFD and SMSSD would mean that individual fault slip rates may be lower bounds. Without paleoseismic investigations and dating of offset surfaces in southern Malawi, it is difficult to test this point. Nevertheless, reactivation analysis that encompasses the range of fault orientations in southern Malawi indicates that these faults are favourably oriented in the current stress field (Williams et al., 2019). Therefore, even faults that have been inactive for a considerable time (up to the entire age of the EARS) could still theoretically be reactivated. We also note that slip rates of intra-basin faults in the North Basin of Lake Malawi over the last $75 \mathrm{ka}(0.15$ $0.7 \mathrm{~mm} / \mathrm{yr}$; Shillington et al., 2020) are within the range of estimates of intra-basin faults in the SMSSD (Fig. 9). 

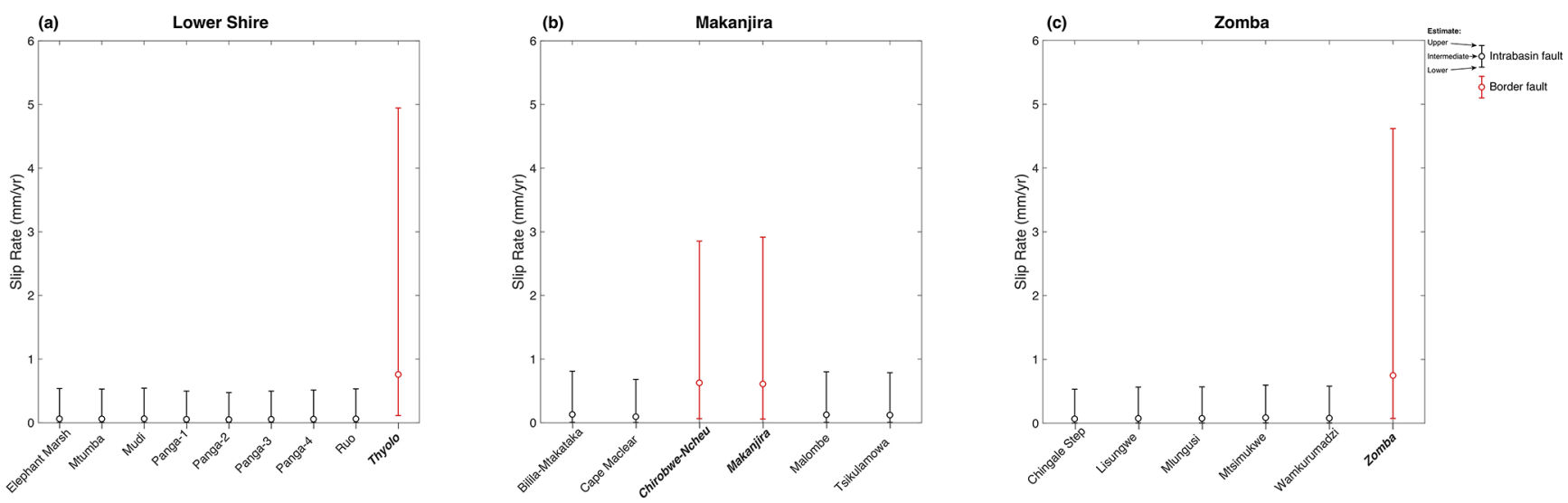

Figure 9. Fault slip rate estimates in the SMSSD, calculated following the approach outlined in Fig. 6 and sorted into different basins in southern Malawi.

\subsection{Sensitivity analysis}

Upper and lower estimates of $R$ differ by up to 3 orders of magnitude in the SMSSD (Fig. 10). To investigate these uncertainties, we performed a multiparameter sensitivity analysis following the methods presented in Box et al. (1978) and Rabinowitz and Steinberg (1991). Full details of this analysis are given in Appendix A. In summary, seven parameters that contribute to uncertainty in $R$ for the central section of the Chingale Step fault are considered (Table 5). By exploring all possible combinations in which these seven parameters are set at their upper or lower estimates, 128 (i.e. $2^{7}$ ) different values of $R$ can be calculated. However, we instead considered 64 parameter combinations that were chosen following a fractional factorial design (Table S1; Box et al., 1978). In this way, parameter combinations that offer little insight into how a system works are omitted, thereby increasing the efficiency of this analysis at minimal cost to its validity (Rabinowitz and Steinberg, 1991). From these combinations, the natural $\log$ of the average value of $R$ when a parameter $(k)$ is set at its upper $(\overline{\ln R}(k+))$ and lower $(\overline{\ln R}(k-))$ value is calculated and the difference between these values defines the parameter effect ( $A$; Rabinowitz and Steinberg, 1991):

$A=\overline{\ln R}(k+)-\overline{\ln R}(k-)$

This analysis indicates that $R$ is most sensitive to uncertainties in the partitioning of strain between border and intrabasin faults in the rift (i.e. $\alpha_{\text {if }} / n_{\text {if }}$ ), the rift extension rate $(v)$, and the $C_{2}$ parameter in Eq. (5), and it is least sensitive to uncertainties in the rift's extension azimuth and the $C_{1}$ parameter in Eq. (5) (Table 5). If, however, $v$ and its associated uncertainties were estimated using a different Nubia-Rovuma Euler pole solution (Fig. A1; Table 3; Stamps et al., 2008), $R$ estimates are least sensitive to $v$ and most sensitive to $C_{2}$ (Table 5). There are no interaction effects between two separate parameters that may influence their effect on $R$ (Table S2).

\section{Discussion}

\subsection{Implications for seismic hazard in southern Malawi}

The existence of active faults within southern Malawi poses a significant risk to the 7.75 million people living in this region (Malawi National Statistics Office, 2018) as well as those living adjacent to the rift in northern Mozambique (Fig. 11a). Furthermore, with population growth at an annual rate of $2.7 \%$ in southern Malawi (Malawi National Statistics Office, 2018), this risk will increase over the coming decades. The rapidly growing city of Blantyre (population of 800000 ; Malawi National Statistics Office, 2018), which is in the footwall of both the relatively fast slipping (intermediate estimates $\sim 0.8 \mathrm{~mm} / \mathrm{yr}$ ) Zomba and Thyolo faults is at a particularly high risk (Fig. 11a).

Intermediate estimates in the SMSSD for $M_{\mathrm{W}}$ 5.4-7.8 earthquakes and fault recurrence intervals $(R)$ of $10^{3}$ $10^{4}$ years (Fig. 11) imply that southern Malawi's seismic hazard is characterised by infrequent large-magnitude events. Indeed, faults in this region may host earthquakes comparable to the largest historical continental normal fault earthquakes $\left(\sim M_{\mathrm{W}} 7.5\right.$; Valentini et al., 2020$)$; although relatively rare, $>150 \mathrm{~km}$ long normal faults have been mapped elsewhere, and these would be capable of even larger events (Styron and Pagani, 2020).

\subsection{Improving earthquake source estimates in the SMSSD}

One of the purposes of collating the SMSSD was to identify current knowledge gaps in our understanding of active faulting and seismic hazard in southern Malawi. Our sensitivity analysis (Sect. 5.4) indicates that the two biggest factors contributing to uncertainty in $R$ in the SMSSD is related to our understanding of the distribution and rate of extension $(v)$ in southern Malawi (Table 5). In particular, there is considerable uncertainty in the position of the Nubia-Rovuma 

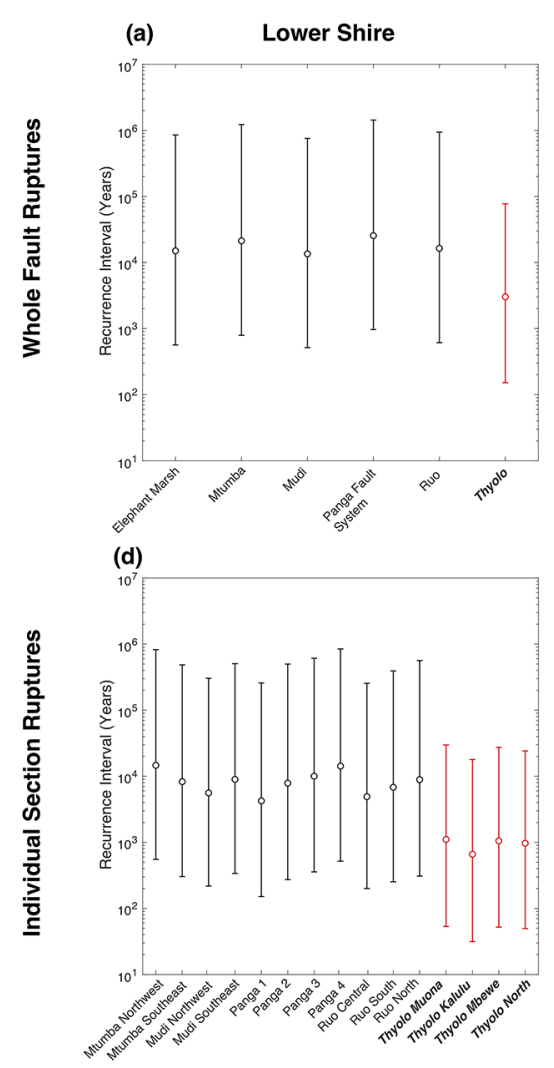
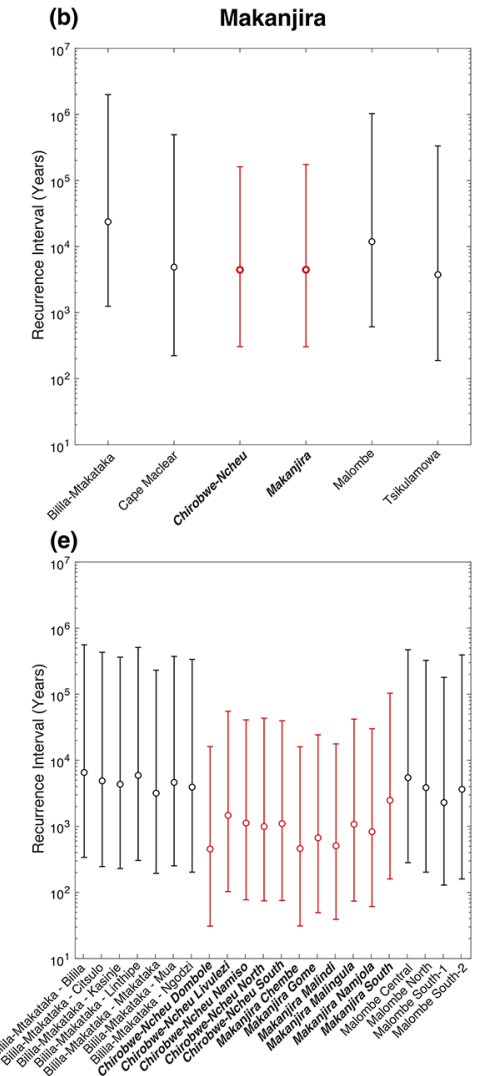
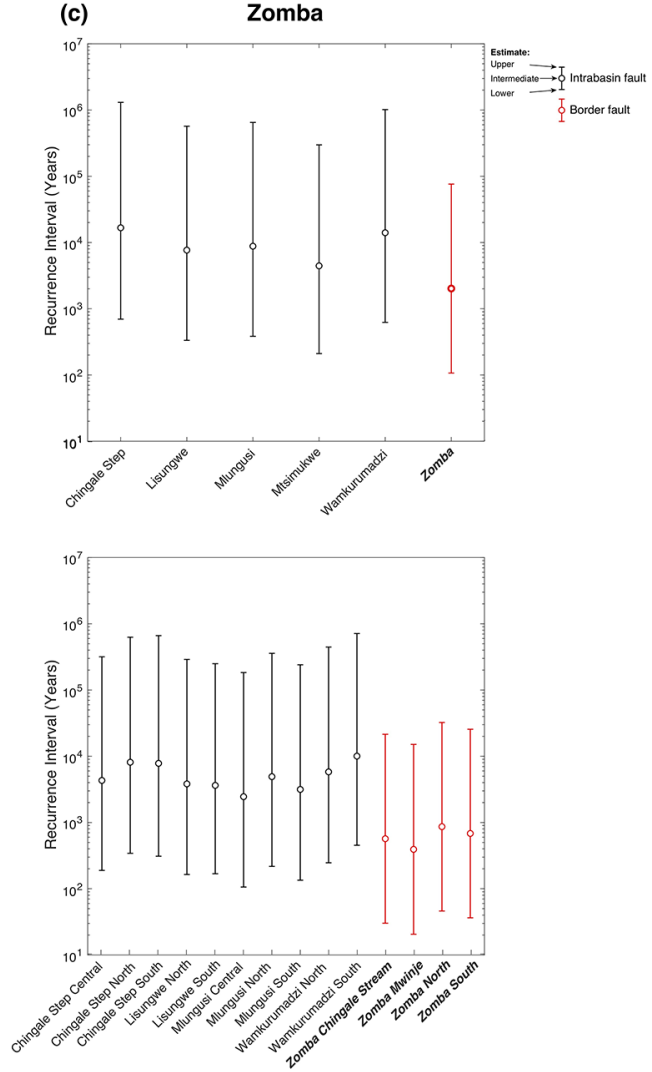

Figure 10. Recurrence interval $(R)$ estimates in the SMSSD for (a-c) whole-fault ruptures and (d-f) individual-section ruptures. Note, $R$ estimates for each Panga Fault are included in panel (d), and a multi-fault rupture is shown in panel (a).

Table 5. Parameters and their associated upper and lower levels used in the sensitivity analysis for recurrence interval $(R)$ calculations for the Chingale Step fault central section using the Stamps et al. (2008) (S08) and Saria et al. (2013) (S13) Nubia-Rovuma Euler poles (Fig. A1). The main effect of each parameter $(A)$ for each geodetic model is then also reported. See Appendix A for full details of this analysis.

\begin{tabular}{|c|c|c|c|c|}
\hline Parameter & $\begin{array}{l}\text { Lower } \\
\text { level }\end{array}$ & $\begin{array}{l}\text { Upper } \\
\text { level }\end{array}$ & $\begin{array}{l}\text { S08 parameter } \\
\text { main effect }(A)\end{array}$ & $\begin{array}{l}\text { S13 parameter } \\
\text { main effect }(A)\end{array}$ \\
\hline $\begin{array}{l}\text { Component of regional } \\
\text { extensional strain }\left(\alpha_{\text {if }} / n_{\text {if }}\right)\end{array}$ & 0.1 & 0.02 & 1.88 & 3.05 \\
\hline $\begin{array}{l}\text { Rift extension rate } \\
(v, \mathrm{~mm} / \mathrm{yr})\end{array}$ & $\begin{array}{l}2.56(\mathrm{~S} 08) \\
0.2(\mathrm{~S} 13)\end{array}$ & $\begin{array}{l}3.12(\mathrm{~S} 08) \\
2.53(\mathrm{~S} 13)\end{array}$ & 0.20 & 2.54 \\
\hline Rift extension azimuth $(\varphi)$ & $085^{\circ}$ & $061^{\circ}$ & 0.32 & 0.32 \\
\hline Fault $\operatorname{dip}(\delta)$ & $65^{\circ}$ & $40^{\circ}$ & 0.59 & 0.59 \\
\hline $\begin{array}{l}\text { Leonard (2010) empirically } \\
\text { derived scaling parameter } C_{1}\left(\mathrm{~m}^{1 / 3}\right)\end{array}$ & 12 & 25 & 0.37 & 0.37 \\
\hline $\begin{array}{l}\text { Leonard (2010) empirically } \\
\text { derived scaling parameter } C_{2}\end{array}$ & 1.5 & 12 & 2.08 & 2.08 \\
\hline Rupture length $(L, \mathrm{~km})$ & $\begin{array}{l}9.6 \text { (individual } \\
\text { section, } L_{\mathrm{sec}} \text { ) }\end{array}$ & $\begin{array}{l}38.0 \text { (whole fault, } \\
\left.L_{\text {fault }}\right)\end{array}$ & 1.15 & 1.15 \\
\hline
\end{tabular}


(a)

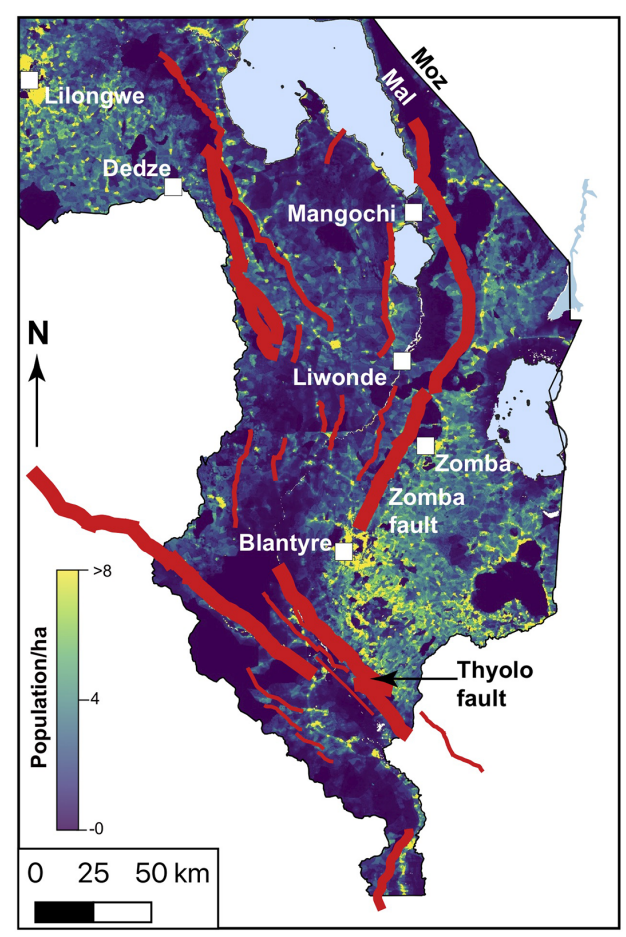

SMAFD fault weighted

by slip rate $(\mathrm{mm} / \mathrm{yr})$

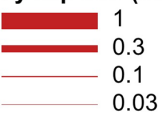

(b)

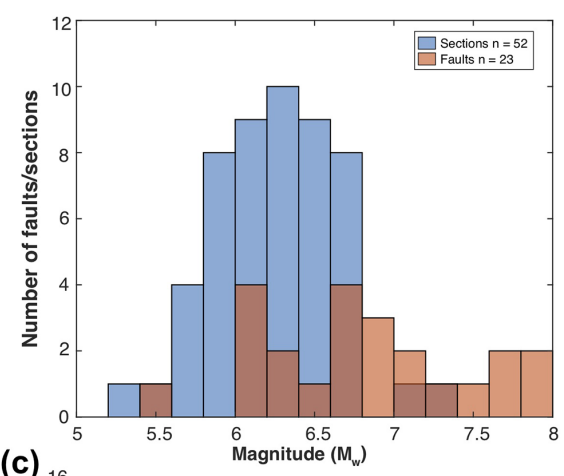

(c)

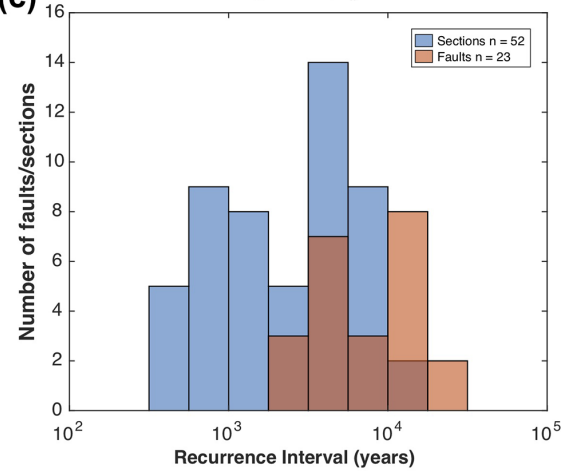

Figure 11. (a) Faults in the SMAFD with lines weighted by intermediate estimates of fault slip rate in the SMSSD. The fault map is underlain by population density, where the pixel size is 3 arcsec (approximately 1 ha), as derived from WorldPop predicted 2020 datasets for Malawi (WorldPop, 2018) with major population centres also highlighted. Note that the population density in these places may exceed 100 people per hectare. The area shown is the same as in Fig. 2. Histograms show the range of (b) earthquake magnitudes and (c) recurrence interval estimates in the SMSSD from intermediate branches in Fig. 6.

Euler pole (Fig. A1; Saria et al., 2013), and we would not expect such large differences between upper and lower fault slip rate estimates by following our systems-based approach elsewhere. Although the uncertainties associated with $v$ in the SMSSD could be reduced if an alternative solution for the Nubia-Rovuma Euler pole was applied (Fig. A1, Tables 5, S2; Stamps et al., 2008), this solution uses fewer Global Positioning System (GPS) sites and a shorter position time series (Saria et al., 2013). Therefore, in the short term, the best refinements to $R$ estimates may come from new regional geodetic data and further high-resolution topographic analysis (e.g. Daly et al., 2020; Stamps et al., 2020; Wedmore et al., 2020a).

Directly measuring on-fault slip rates and paleoseismicity would provide more robust $R$ estimates than the modelderived estimates in SMSSD. However, careful site selection would be required for these analyses in southern Malawi because of its potential for large $(\sim 10 \mathrm{~m})$ single-event displacements (Hodge et al., 2020). Furthermore, these investigations carry large inherent uncertainties in low-strain-rate regions like southern Malawi if only a few earthquakes are sampled, as these events may be temporally clustered (Nicol et al., 2006, 2016b; Pérouse and Wernicke, 2017; Taylor-Silva et al., 2020).

When considering how different rupture magnitude estimates in the SMSSD influence $R$, the main source of uncertainty is the $C_{2}$ parameter from the Leonard (2010) regressions (Table 5). This factor controls the amount of displacement for a given rupture area (Leonard, 2010). It is therefore likely related to earthquake stress drops, and uncertainty in $C_{2}$ in southern Malawi will only be reduced by recording more events here or in similar tectonic environments - i.e. normal fault earthquakes in regions with low $(\sim 1-10 \mathrm{~mm} / \mathrm{yr})$ extension rates and thick $(20-35 \mathrm{~km})$ seismogenic crust. 


\section{Incorporation of the SMSSD into probabilistic seismic hazard analysis}

The SMSSD contains the attributes (earthquake magnitudes and $R$ estimates) that allow it to be used as a source model for future PSHA in southern Malawi. However, in common with other low-strain-rate regions with limited paleoseismic information (e.g. Cox et al., 2012; Villamor et al., 2018), there are various aleatory (i.e. the uncertainty related to unpredictable nature of future event) and epistemic (i.e. the uncertainty due to incomplete knowledge and data) uncertainties. Firstly, as noted in Sect. 5.2, it is unrealistic that the intermediate, lower, and upper value of each attribute in the SMSSD logic tree has an equal probability (Fig. 6). This could be formalised by treating these attributes as continuous variables and assigning probability distribution functions to them.

Implicit in the $R$ estimates in the SMSSD is that each earthquake source can only host events of two sizes: "individual sections" and "whole faults". Therefore, it does not consider multi-segment ruptures that do not rupture the entire fault. Although not strictly the same, the SMSSD therefore follows many aspects of the characteristic earthquake model (i.e. each earthquake source only hosts event of one size) whose applicability remains contentious (Kagan et al., 2012; Page and Felzer, 2015; Stirling and Gerstenberger, 2018). An alternative approach to model $R$ in southern Malawi would be to allow each fault to host a range of earthquake sizes that follow a frequency-magnitude distribution that is consistent with its moment rate (Youngs and Coppersmith, 1985), with this moment rate derived from the instrumental record and data incorporated into the SMSSD.

Finally, there are likely active faults in Malawi that are not included in the SMAFD and SMSSD. Thus, we recommend that future PSHA in southern Malawi should also consider "off-fault" areal seismic sources by using the instrumental record (e.g. Field et al., 2014; Gerstenberger et al., 2020; Hodge et al., 2015; Morell et al., 2020; Stirling et al., 2012). Many of the challenges discussed above can be addressed through the creation of synthetic seismic catalogues, which are then used as a PSHA source (Hodge et al., 2015).

\section{Conclusions}

We describe a new systems-based approach that combines geologic and geodetic data to estimate fault slip rates and earthquake recurrence intervals in regions with little historical or paleoseismic earthquake data. This approach is used to develop the South Malawi Active Fault Database (SMAFD) and South Malawi Seismogenic Source Database (SMSSD), geospatial databases designed to direct future research and aid seismic hazard analysis and planning.

In the SMAFD, we document 23 active faults that have accumulated displacement during East African rifting in southern Malawi. In the SMSSD, fault slip rates, earthquake magnitudes, and recurrence intervals are estimated for the active faults compiled in the SMAFD. The SMSSD indicates the potential for $M_{\mathrm{W}}$ 6.5-7.8 earthquakes throughout southern Malawi. However, slow geodetically derived extension rates $(\sim 1 \mathrm{~mm} / \mathrm{yr})$ imply low fault slip rates $(0.001-5 \mathrm{~mm} / \mathrm{yr})$, and so the recurrence intervals of $M_{\mathrm{W}}>7$ events are estimated to be $10^{2}-10^{6}$ years. The large range of these estimated recurrence times reflects aleatory uncertainty on fault rupture scenarios and epistemic uncertainties in fault-scaling relationships, fault slip rates, and fault geometry. Sensitivity analysis suggests the biggest reduction in uncertainties would come from improved knowledge of fault slip rates through paleoseismic investigations or geodetic studies. Nevertheless, the combination of long, highly coupled, low-sliprate faults and a short ( $<65$ years) instrumental record imply that the SMAFD and SMSSD are important sources of information for future seismic hazard analyses in the region. In this respect, the development of SMSSD is timely as the seismic risk of southern Malawi is growing due to rapid population growth, urbanisation, and seismically vulnerable building stock. Similar challenges exist elsewhere along the EARS, which may also be partially addressed by following the framework provided by the SMAFD and SMSSD. 


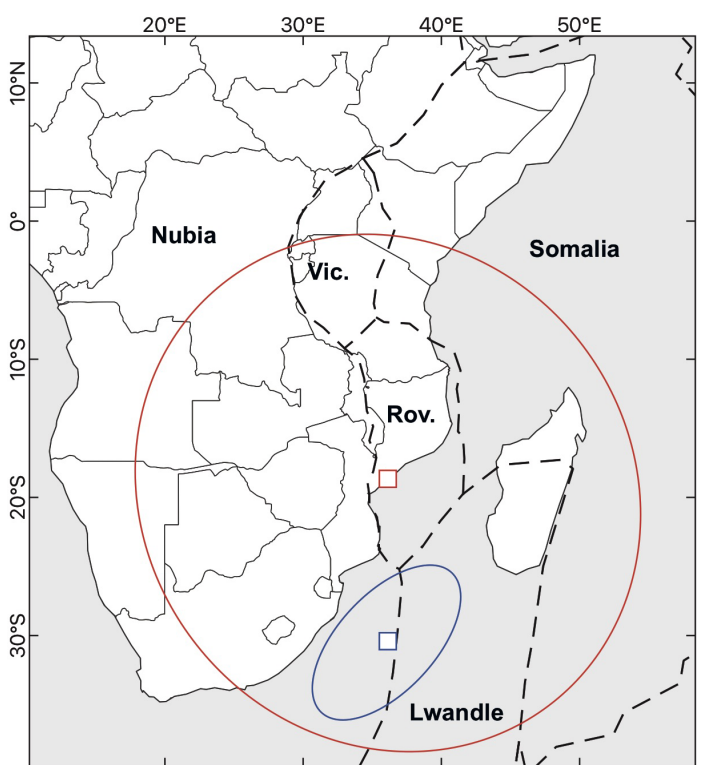

Nubia-Rovuma Euler pole and

$95 \%$ confidence error ellipse:

Saria et al. (2013)

Stamps et al. (2008)

Figure A1. Plate boundaries in East Africa with location and uncertainty of the Nubia-Rovuma Euler pole derived by Saria et al. (2013) and Stamps et al. (2008). "Vic." denotes Victoria, and "Rov." denotes Rovuma. Modified after Saria et al. (2013).

\section{Appendix A: A multiparameter sensitivity analysis for recurrence interval estimates in the South Malawi Active Fault Database}

Recurrence interval estimates in the South Malawi Seismogenic Database (SMSSD) vary by over 3 orders of magnitude (Fig. 10). These uncertainties are not unexpected in a region like Malawi with no paleoseismic data and an incomplete instrumental seismic record (Cox et al., 2012; Villamor et al., 2018), and they can be accounted for in probabilistic seismic hazard analysis (PSHA) using synthetic seismicity catalogues (Hodge et al., 2015). Nevertheless, by conducting a sensitivity analysis on the logic tree approach used to calculate these recurrence intervals (Fig. 6), it is possible to determine which parameters contribute most to this uncertainty and, in turn, guide future research directions that will help constrain them in future iterations of the SMSSD. This analysis is briefly described in the main text (Sect. 5.4, Table 5) and is documented fully below.

Here, we follow the multiparameter sensitivity analysis presented by Rabinowitz and Steinberg (1991). This study conducted sensitivity analysis for the parameters that feed into PSHA, where the output metric is the probability of exceedance of a given level of ground shaken. For the SMSSD, we adapt this method to test the sensitivity of seven parame- ters that are used to calculate earthquake recurrence intervals ( $R$; Eq. A1; Table 5). This metric is chosen as it fully incorporates the aleatory uncertainties in rupture length as well as epistemic uncertainties in fault slip rates and the Leonard (2010) scaling relationships (Fig. 6). This analysis is performed for the Chingale Step fault central section (Fig. 4), where like all intra-basin faults in the SMSSD, $R$ is calculated by

$R=\frac{\left(\frac{5}{6} \log L+\frac{1}{2} \log C_{1}+\log C_{2}\right)\left(n_{\mathrm{if}} \cos \delta\right)}{\alpha_{\mathrm{if}} v \cos (\theta-\phi)}$

Here, $L$ is rupture length and depends on whether an individual-section $\left(L_{\mathrm{sec}}\right)$ or whole-fault $\left(L_{\text {fault }}\right)$ rupture is considered, $C_{1}$ and $C_{2}$ are empirically derived constants from Leonard (2010), $\delta$ is fault dip, $\theta$ is the fault slip azimuth, $v$ and $\varphi$ are the rift extension rate and azimuth respectively, $\alpha_{\text {if }}$ is a weighting of rift extension for intra-basin faults, and $n_{\text {if }}$ is the number of mapped intra-basin faults $\left(n_{\text {if }}\right)$ in the basin.

Equation (A1) is essentially a combination of Eqs. (3), (5), and (6) in the main text, and its application with the SMSSD logic tree to calculate $R$ for the Chingale Step fault central section is shown in Fig. 7. There are five intra-basin faults in the Zomba Graben where the Chingale Step fault is situated (Fig. 2), and this parameter is not treated as an uncertainty in this analysis. However, for simplicity, it is combined with $\alpha_{\text {if }}$ to give the "component of rift extensional strain" parameter, which is defined by $\alpha_{\text {if }} / n_{\text {if }}$ (Table 5). Assuming that the Chingale Step fault is a normal fault (Wedmore et al., 2020a; Williams et al., 2019), $\theta$ is the fault dip direction, and differs by only $4^{\circ}$ depending on whether the whole fault ruptures or just the central section (Fig. 7). Hence, uncertainty in this parameter is not considered here, and it is set at $290^{\circ}$, which is the average value for these two rupture scenarios. When assessing the influence of $v$, we consider two geodetic models (Fig. A1; Saria et al., 2013; Stamps et al., 2008) and perform this sensitivity analysis for both.

The method presented by Rabinowitz and Steinberg (1991) involves a two-level fractional factorial multiparameter design, where each parameter is restricted to the two levels which will give lower or upper estimates of $R$ (Table 5). Ideally, these levels would be symmetric about the intermediate case; however, in the SMSSD this is not possible for the $v, L$, and $C_{2}$. Compared with a "one-at-a-time (OAT)" parameter analysis, a multiparameter analysis allows us to assess how different parameters interact with each other and, thus, more fully explore the parameter space (Rabinowitz and Steinberg, 1991). This is achieved through a factorial design, which for the seven parameters $(k)$ tested here would generate 128 (i.e. $2^{7}$ ) possible combinations in a full two-level factorial approach. However, in a fractional factorial design, just a subset of these combinations is assessed. This approach recognises that many of the combinations in a full factorial design offer little insight into how a system works and that 
(a)

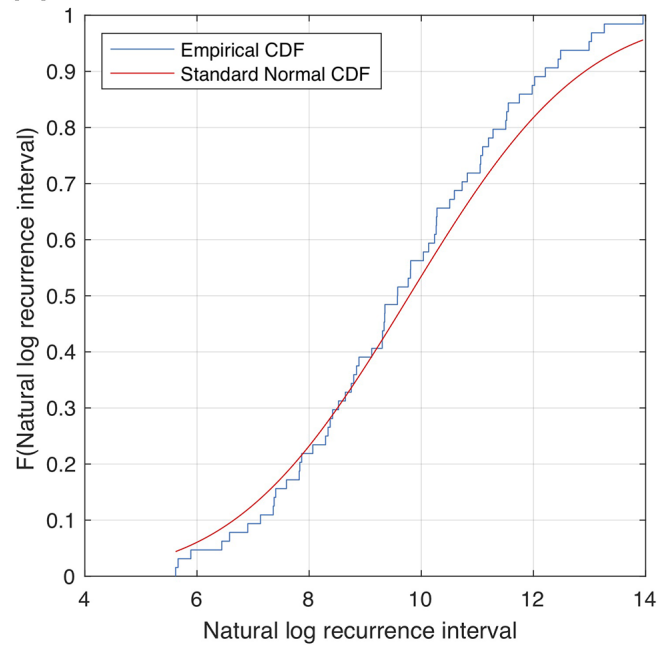

(b)

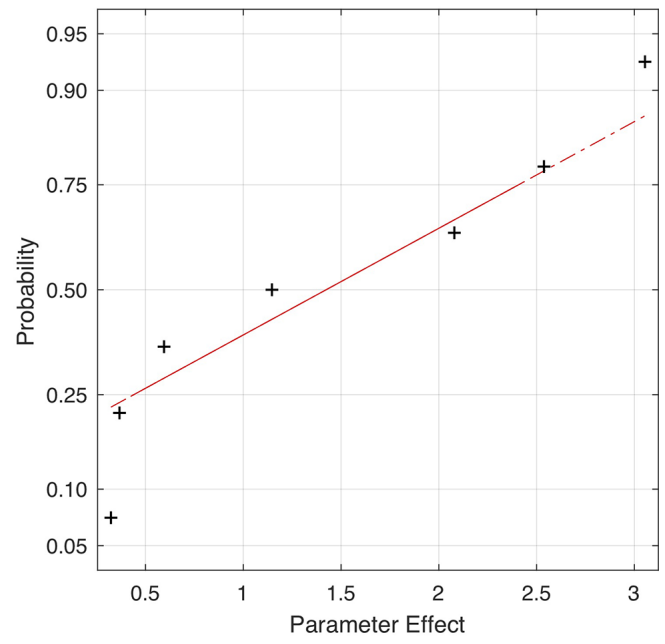

Figure A2. (a) Cumulative distribution function (CDF) of the natural log of the recurrence intervals calculated for the Chingale Step fault central section using the various parameter combinations listed in Table S1 (blue line). This CDF is compared to a standard normal CDF (red line) with the same mean value and standard deviation as the values in Table S1. (b) A normal probability plot of the parameter effects assessed in the sensitivity analysis and reported in Table 5. The most important effects are those that plot above a standard normal distribution (red line). The line is solid when within the first and third quartiles of data and is dashed when outside of this region.

this can instead be achieved at minimal cost to the results by considering a carefully selected subset of these combinations (Box et al., 1978; Rabinowitz and Steinberg, 1991). In this analysis, $2^{k-p}$ combinations are assessed, where $p$ is the number of generators and is set at one. This results in the assessment of 64 combinations (Table S1) and a "resolution" of five, which means it is possible to estimate the main effects of each parameter (Eq. A2), interactions between two parameters (Eq. A3), but not interactions between three parameters (Box et al., 1978).

The main effect $(A)$ of one parameter (e.g. fault dip, $\delta$ ) is quantified from the difference between the average of the natural $\log$ of recurrence interval $(\overline{\ln R})$ for the 32 combinations in Table $\mathrm{S} 1$ when a parameter was at its upper level (i.e. $\delta+=40^{\circ}$ ) and $\overline{\ln R}$ for the 32 combinations when the parameter was at its low level (i.e. $\delta-=65^{\circ}$ ):

$A=\overline{\ln R}(\delta+)-\overline{\ln R}(\delta-)$

By applying a multiparameter approach it is also possible to quantify the parameter-parameter interaction effects - for example, if the effect of $\delta$ depends on the choice of rift extension azimuth $(\varphi)$. To do this, the results in Table $S 1$ can be divided into two sets with $2^{k-p-1}$ combinations each depending on which level of $\delta$ was applied. Following the table designs developed by Box et al. (1978), each set of 32 combinations will have 16 combinations when $\varphi$ was at is upper level $(\varphi+)$ and 16 combinations when $\varphi$ was at its lower level $(\varphi-)$. The effect of $\delta$ on each level of $\varphi$ (i.e. $\delta \varphi)$ is then calculated from the corresponding differences in $\overline{\ln R}$ (Rabinowitz and Steinberg, 1991):

$$
\begin{gathered}
\delta \phi=(\overline{\ln R}(\delta+\phi+)-\overline{\ln R}(\delta-\phi+)) \\
-(\ln \bar{R}(\delta+\phi-)-\overline{\ln R}(\delta-\phi-))
\end{gathered}
$$

If there is no interaction effect between these two parameters, $\delta \varphi$ is zero; otherwise, the size of the effect is proportional to the magnitude of $\delta \varphi$. In addition, we demonstrate our results in terms of an empirical cumulative distribution function for the values of $\ln R$ reported in Table 1 (Fig. A2a) and, following Rabinowitz and Steinberg (1991), values of $A$ in a normal probability plot (Fig. A2b).

If the Saria et al. (2013) model is used to provide estimates of $v$ in this sensitivity analysis, the parameter that contributes most to uncertainties of $R$ in the SMSSD is the component of regional extensional strain that each fault accommodates ( $A=3.05$, Table 5 ). This essentially means that $\ln R$ is higher by 3.05 when this component is set at its high value compared with its lower value, or, in other words, that $R$ is $\sim 21$ times $\left(e^{3.05}\right)$ higher when $10 \%$ of regional extensional strain is assigned to the Chingale Step fault as opposed to $2 \%$. The importance of this parameter is also demonstrated by the fact that it does not plot close to the normal distribution line in Fig. A2b. The parameters with the next highest main effect on $R$ are $v$ and $C_{2}$, whereas estimates of $R$ are least sensitive to uncertainties in $\varphi$ (Table 5). If, however, estimates of $v$ are provided by the Stamps et al. (2008) model (Fig. A1), estimates of $R$ are considerably less sensitive to uncertainties in rift extension rates, and the $C_{2}$ parameter has the biggest influence on $R$ (Table 5). Multiparameter effects are all equal to zero (Table S2) regardless of geodetic model; thus, the sen- 
sitivity of each of these parameters is independent of changes in other parameters.

The results of the sensitivity analysis reported here are specific to estimates of $R$ for the Chingale Step fault central section; however, results should be broadly applicable to all other faults in the SMSSD, as $R$ was calculated following the same steps. Nevertheless, there will be differences for faults that are not segmented (where $L$ is not an uncertainty) or that have more than the three sections mapped along the Chingale Step fault (e.g. the seven-section Bilila-Mtakataka Fault). The uncertainty in the weighting of rift extension may also be different for border faults, as the weighting factor $\left(\alpha_{\mathrm{bf}}\right)$ is varied between 0.5 and 0.9 in these cases. The results of this analysis are discussed further in Sect. 5.4 and 6.2 in the main text. 
Data availability. The South Malawi Active Fault Database (SMAFD), South Malawi Seismogenic Source Database (SMSSD), and a GIS file for all other faults in Malawi are available in the Supplement as shapefiles. In addition, an Excel file is included for the SMSSD where the earthquake source parameters were performed. All files are available under Creative Commons Attribution-ShareAlike (CC-BY-SA 4.0) licence 4.0.

Supplement. The supplement related to this article is available online at: https://doi.org/10.5194/se-12-187-2021-supplement.

Author contributions. JNW and LNJW led the fault mapping from TanDEM-X data, and HM led the fault mapping using aeromagnetic data. All authors participated in the fieldwork. LNJW conducted the analysis of geodetic data. JNW designed the method to obtain fault slip rates and earthquake source parameters with input from all co-authors. JB and $\AA$ F secured the funding for this project. All authors contributed to paper preparation, but JNW had the primary responsibility.

Competing interests. The authors declare that they have no conflict of interest.

Acknowledgements. This work is supported by the EPSRC Global Challenges Research Fund PREPARE project (grant no. EP/P028233/1). TanDEM-X data were provided through DLR proposal DEM_GEOL0686. The Geological Survey Department of Malawi kindly gave us access to the 2013 aeromagnetic surveys across Malawi. We gratefully acknowledge thoughtful and constructive reviews from Richard Styron and Folarin Kolawole. We also thank Katsu Goda and Mark Stirling for useful discussions on developing this database as well as Mike Floyd for his assistance with calculating geodetic extension rates from Euler poles.

Financial support. This research has been supported by the Engineering and Physical Sciences Research Council (grant no. $\mathrm{EP} / \mathrm{P} 028233 / 1)$.

Review statement. This paper was edited by Zoe Mildon and reviewed by Richard Styron and Folarin Kolawole.

\section{References}

Accardo, N. J., Shillington, D. J., Gaherty, J. B., Scholz, C. A., Nyblade, A. A., Chindandali, P. R. N., Kamihanda, G., McCartney, T., Wood, D., and Wambura Ferdinand, R.: Constraints on Rift Basin Structure and Border Fault Growth in the Northern Malawi Rift From 3-D Seismic Refraction Imaging, J. Geophys. Res.-Sol. Ea., 123, 10003-10025, https://doi.org/10.1029/2018JB016504, 2018.
Agostini, A., Bonini, M., Corti, G., Sani, F., and Manetti, P.: Distribution of Quaternary deformation in the central Main Ethiopian Rift, East Africa, Tectonics, 30, TC4010, https://doi.org/10.1029/2010TC002833, 2011a.

Agostini, A., Bonini, M., Corti, G., Sani, F., and Mazzarini, F.: Fault architecture in the Main Ethiopian Rift and comparison with experimental models: Implications for rift evolution and Nubia-Somalia kinematics, Earth Planet. Sc. Lett., 301, 479-492, https://doi.org/10.1016/j.epsl.2010.11.024, 2011b.

Ayele, A.: Probabilistic seismic hazard analysis (PSHA) for Ethiopia and the neighboring region, J. African Earth Sci., 134, 257-264, https://doi.org/10.1016/j.jafrearsci.2017.06.016, 2017.

Basili, R., Valensise, G., Vannoli, P., Burrato, P., Fracassi, U., Mariano, S., Tiberti, M. M., and Boschi, E.: The Database of Individual Seismogenic Sources (DISS), version 3: Summarizing 20 years of research on Italy's earthquake geology, Tectonophysics, 453, 20-43, https://doi.org/10.1016/j.tecto.2007.04.014, 2008.

Beauval, C., Marinière, J., Yepes, H., Audin, L., Nocquet, J. M., Alvarado, A., Baize, S., Aguilar, J., Singaucho, J. C., and Jomard, H.: A new seismic hazard model for ecuador, B. Seismol. Soc. Am., 108, 1443-1464, https://doi.org/10.1785/0120170259, 2018.

Biasi, G. P. and Wesnousky, S. G.: Steps and gaps in ground ruptures: Empirical bounds on rupture propagation, B. Seismol Soc. Am., 106, 1110-1124, https://doi.org/10.1785/0120150175, 2016.

Biggs, J., Nissen, E., Craig, T., Jackson, J., and Robinson, D. P.: Breaking up the hanging wall of a rift-border fault: The 2009 Karonga earthquakes, Malawi, Geophys. Res. Lett., 37, L11305, https://doi.org/10.1029/2010GL043179, 2010.

Billings, S. E. and Kattenhorn, S. A.: The great thickness debate: Ice shell thickness models for Europa and comparisons with estimates based on flexure at ridges, Icarus, 177, 397-412, https://doi.org/10.1016/j.icarus.2005.03.013, 2005.

Bloomfield, K.: The geology of the Port Herald Area, Bull. Geol Surv. Malawi, 9, 76 pp., 1958.

Bloomfield, K.: The Geology of the Zomba Area, Bull. Geol. Surv. Malawi, 16, 193 pp., 1965.

Bloomfield, K. and Garson, M. S.: The Geology of the Kirk RangeLisungwe Valley Area, Bull. Geol. Surv. Malawi, 17, 234 pp. 1965.

Box, G. E. P., Hunter, W. G., and Hunter, J. S.: Statistics for experimenters, John Wiley and SBei ons New York, 653 pp., 1978.

Brace, W. F. and Byerlee, J. D.: Stick-slip as a mechanism for earthquakes, Science, 153, 990-992, 1966.

Braun, J. and Beaumont, C.: Three-dimensional numerical experiments of strain partitioning at oblique plate boundaries: implications for contrasting tectonic styles in the southern Coast Ranges, California, and central South Island, New Zealand, J. Geophys. Res., 100, 18059-18074, https://doi.org/10.1029/95jb01683, 1995.

Buck, W. R.: Modes of continental lithospheric extension, J. Geophys. Res., 96, 20161-20178, https://doi.org/10.1029/91jb01485, 1991.

Calais, E., Camelbeeck, T., Stein, S., Liu, M., and Craig, T. J.: A new paradigm for large earthquakes in stable continental plate interiors, Geophys. Res. Lett., 43, 1621-10637, https://doi.org/10.1002/2016GL070815, 2016. 
Castaing, C.: Post-Pan-African tectonic evolution of South Malawi in relation to the Karroo and recent East African rift systems, Tectonophysics, 191, 55-73, https://doi.org/10.1016/00401951(91)90232-H, 1991.

Chapola, L. S. and Kaphwiyo, C. E.: The Malawi rift: Geology, tectonics and seismicity, Tectonophysics, 209, 159-164, https://doi.org/10.1016/0040-1951(92)90017-Z, 1992.

Childs, C., Watterson, J., and Walsh, J. J.: Fault overlap zones within developing normal fault systems, J. Geol. Soc., 152, 535-549, https://doi.org/10.1144/gsjgs.152.3.0535, 1995.

Chisenga, C., Dulanya, Z., and Jianguo, Y.: The structural reinterpretation of the Lower Shire Basin in the Southern Malawi rift using gravity data, J. African Earth Sci., 149, 280-290, https://doi.org/10.1016/j.jafrearsci.2018.08.013, 2019.

Christophersen, A., Litchfield, N., Berryman, K., Thomas, R., Basili, R., Wallace, L., Ries, W., Hayes, G. P., Haller, K. M., Yoshioka, T., Koehler, R. D., Clark, D., Wolfson-Schwehr, M., Boettcher, M. S., Villamor, P., Horspool, N., Ornthammarath, T., Zuñiga, R., Langridge, R. M., Stirling, M. W., Goded, T., Costa, C., and Yeats, R.: Development of the Global Earthquake Model's neotectonic fault database, Nat. Hazards, 79, 111-135, https://doi.org/10.1007/s11069-015-1831-6, 2015.

Clark, D., McPherson, A., and Van Dissen, R.: Longterm behaviour of Australian stable continental region (SCR) faults, Tectonophysics, 566-567, 1-30, https://doi.org/10.1016/j.tecto.2012.07.004, 2012.

Cornell, C. A.: Engineering seismic risk analysis, B. Seismol. Soc. Am., 58, 1583-1606, https://doi.org/10.1016/01676105(83)90143-5, 1968.

Corti, G.: Evolution and characteristics of continental rifting: Analog modeling-inspired view and comparison with examples from the East African Rift System, Tectonophysics, 522, 1-33, https://doi.org/10.1016/j.tecto.2011.06.010, 2012.

Corti, G., Philippon, M., Sani, F., Keir, D., and Kidane, T.: Reorientation of the extension direction and pure extensional faulting at oblique rift margins: Comparison between the Main Ethiopian Rift and laboratory experiments, Terra Nova, 25, 396404, https://doi.org/10.1111/ter.12049, 2013.

Cowie, P. A., Roberts, G. P., Bull, J. M., and Visini, F.: Relationships between fault geometry, slip rate variability and earthquake recurrence in extensional settings, Geophys. J. Int., 189, 143-160, https://doi.org/10.1111/j.1365-246X.2012.05378.x, 2012.

Cox, S. C., Stirling, M. W., Herman, F., Gerstenberger, M., and Ristau, J.: Potentially active faults in the rapidly eroding landscape adjacent to the Alpine Fault, central Southern Alps, New Zealand, Tectonics, 31, TC2011, https://doi.org/10.1029/2011TC003038, 2012.

Craig, T. J., Jackson, J. A., Priestley, K., and Mckenzie, D.: Earthquake distribution patterns in Africa: Their relationship to variations in lithospheric and geological structure, and their rheological implications, Geophys. J. Int., 185, 403-434, https://doi.org/10.1111/j.1365-246X.2011.04950.x, 2011.

Daly, M. C., Green, P., Watts, A. B., Davies, O., Chibesakunda, F., and Walker, R.: Tectonics and Landscape of the Central African Plateau and their Implications for a Propagating Southwestern Rift in Africa, Geochem. Geophys. Geosys., 21, e2019GC008746, https://doi.org/10.1029/2019GC008746, 2020 .
Delvaux, D.: Age of Lake Malawi (Nyasa) and water level fluctuations, Mus. roy. Afrr. centr., Tervuren (Belg.), Dept. Geol. Min., Rapp. ann. 1993, 1994, 108, 99-108, 1995.

Delvaux, D. and Barth, A.: African stress pattern from formal inversion of focal mechanism data, Tectonophysics, 482, 105-128, https://doi.org/10.1016/j.tecto.2009.05.009, 2010.

Delvaux, D., Mulumba, J. L., Sebagenzi, M. N. S., Bondo, S. F., Kervyn, F., and Havenith, H. B.: Seismic hazard assessment of the Kivu rift segment based on a new seismotectonic zonation model (western branch, East African Rift system), J. African Earth Sci., 134, 831-855, https://doi.org/10.1016/j.jafrearsci.2016.10.004, 2017.

Dixey, F.: The Nyasaland section of the great rift valley, Geogr. J., 68, 117-137, 1926.

Dixey, F.: The Nyasa-Shire Rift, Geogr. J., 91, 51-56, 1938.

Dulanya, Z.: A review of the geomorphotectonic evolution of the south Malawi rift, J. African Earth Sci., 129, 728-738, https://doi.org/10.1016/j.jafrearsci.2017.02.016, 2017.

DuRoss, C. B., Personius, S. F., Crone, A. J., Olig, S. S., Hylland, M. D., Lund, W. R., and Schwartz, D. P.: Fault segmentation: New concepts from the Wasatch Fault Zone, Utah, USA, J. Geophys. Res.-Sol. Ea., 121, 1131-1157, https://doi.org/10.1002/2015JB012519, 2016.

Ebinger, C.: Continental break-up: The East African perspective, Astron. Geophys., 46, 16-21, https://doi.org/10.1111/j.14684004.2005.46216.x, 2005.

Ebinger, C. J.: Tectonic development of the western branch of the East African rift system, Geol. Soc. Am. Bull., 101, 885-903, https://doi.org/10.1130/00167606(1989)101<0885:TDOTWB>2.3.CO;2, 1989.

Ebinger, C. J., Rosendahl, B. R., and Reynolds, D. J.: Tectonic model of the Malawi rift, Africa, Tectonophysics, 141, 215-235, https://doi.org/10.1016/0040-1951(87)90187-9, 1987.

Ebinger, C. J., Oliva, S. J., Pham, T. Q., Peterson, K., Chindandali, P., Illsley-Kemp, F., Drooff, C., Shillington, D. J., Accardo, N. J., Gallacher, R. J., Gaherty, J., Nyblade, A. A., and Mulibo, G.: Kinematics of Active Deformation in the Malawi Rift and Rungwe Volcanic Province, Africa, Geochem. Geophys. Geosyst., 20, 3928-3951, https://doi.org/10.1029/2019GC008354, 2019.

England, P. and Jackson, J.: Uncharted seismic risk, Nat. Geosci., 4, 348-349, https://doi.org/10.1038/ngeo1168, 2011.

Fagereng, Å.: Fault segmentation, deep rift earthquakes and crustal rheology: Insights from the 2009 Karonga sequence and seismicity in the Rukwa-Malawi rift zone, Tectonophysics, 601, 216225, https://doi.org/10.1016/j.tecto.2013.05.012, 2013.

Field, E. H., Arrowsmith, R. J., Biasi, G. P., Bird, P., Dawson, T. E., Felzer, K. R., Jackson, D. D., Johnson, K. M., Jordan, T. H., and Madden, C.: Uniform California earthquake rupture forecast, version 3 (UCERF3) - The time-independent model, B. Seismol. Soc. Am., 104, 1122-1180, 2014.

Fullgraf, T., Zammit, C., Bailly, L., Terrier, M., Hyvonen, E., Backman, B., Karinen, T., Konnunaho, J., Thomas, R., and Tychsen, J.: Geological Mapping and Mineral Assessment Project (GEMMAP) of Malawi, Report Inception Phase - February 2017, available at: https://www.brgm.eu/project/ geological-mapping-mineral-inventory-malawi (last access: 7 January 2020), 2017. 
Gaherty, J. B., Zheng, W., Shillington, D. J., Pritchard, M. E., Henderson, S. T., Chindandali, P. R. N., Mdala, H., Shuler, A., Lindsey, N., Oliva, S. J., Nooner, S., Scholz, C. A., Schaff, D., Ekström, G., and Nettles, M.: Faulting processes during early-stage rifting: Seismic and geodetic analysis of the 2009-2010 Northern Malawi earthquake sequence, Geophys. J. Int., 217, 1767-1782, https://doi.org/10.1093/gji/ggz119, 2019.

Gawthorpe, R. L. and Leeder, M. R.: Tectono-sedimentary evolution of active extensional basins, Basin Res., 12, 195-218, https://doi.org/10.1111/j.1365-2117.2000.00121.x, 2000.

Gerstenberger, M. C., Marzocchi, W., Allen, T., Pagani, M., Adams, J., Danciu, L., Field, E. H., Fujiwara, H., Luco, N., Ma, K. F., Meletti, C., and Petersen, M. D.: Probabilistic Seismic Hazard Analysis at Regional and National Scales: State of the Art and Future Challenges, Rev. Geophys., 58, e2019RG000653, https://doi.org/10.1029/2019RG000653, 2020.

Goda, K., Gibson, E. D., Smith, H. R., Biggs, J., and Hodge, M.: Seismic risk assessment of urban and rural settlements around lake malawi, Front. Built Environ., 2, 2-17, https://doi.org/10.3389/fbuil.2016.00030, 2016.

Goda, K., Kloukinas, P., Risi, R., Hodge, M., Kafodya, I., Ngoma, I., Biggs, J., Crewe, A., Fagereng, A., and Macdonald, J.: Scenario-based seismic risk assessment for Malawi using improved information on earthquake sources and local building characteristics, in 16th European Conference on Earthquake Engineering, 1-12, 2018.

Goitom, B., Werner, M. J., Goda, K., Kendall, J. M., Hammond, J. O. S., Ogubazghi, G., Oppenheimer, C., Helmstetter, A., Keir, D., and Illsley-Kemp, F.: Probabilistic seismic-hazard assessment for Eritrea, B. Seismol. Soc. Am., 107, 1478-1494, https://doi.org/10.1785/0120160210, 2017.

Gómez-Vasconcelos, M. G., Villamor, P., Procter, J., Palmer, A., Cronin, S., Wallace, C., Townsend, D., and Leonard, G.: Characterisation of faults as earthquake sources from geomorphic data in the Tongariro Volcanic Complex, New Zealand, New Zeal. J. Geol. Geophys., 1-12, 2018.

Gupta, H. K.: The Malawi earthquake of March 10, 1989: A report of the macroseismic survey, Tectonophysics, 209, 165-166, https://doi.org/10.1016/0040-1951(92)90018-2, 1992.

Gupta, S., Cowie, P. A., Dawers, N. H., and Underhill, J. R.: A mechanism to explain rift-basin subsidence and stratigraphic patterns through fault-array evolution, Geology, 26, 595-598, https://doi.org/10.1130/00917613(1998)026<0595:AMTERB>2.3.CO, 1998.

Habgood, F.: The geology of the country west of the Shire River between Chikwawa and Chiromo, Bull. Geol. Surv. Malawi, 14, 60 pp., 1963.

Habgood, F., Holt, D. N., and Walshaw, R. D.: The geology of the Thyolo Area, Bull. Geol. Surv. Malawi, 22, 24 pp., 1973.

Hamiel, Y., Baer, G., Kalindekafe, L., Dombola, K., and Chindandali, P.: Seismic and aseismic slip evolution and deformation associated with the 2009-2010 northern Malawi earthquake swarm, East African Rift, Geophys. J. Int., 191, 898-908, https://doi.org/10.1111/j.1365-246X.2012.05673.x, 2012.

Hart, E. and Bryant, W.: Fault-rupture hazard zones in California: Alquist-Priolo Earthquake Fault Zoning Act with Index to Earthquake Fault Zones Maps, 38 pp., 1999.

Heimpel, M. and Olson, P.: A seismodynamical model of lithosphere deformation: Development of continental and oceanic rift networks, J. Geophys. Res.-Sol. Ea., 101, 16155-16176, https://doi.org/10.1029/96jb00168, 1996.

Hellebrekers, N., Niemeijer, A. R., Fagereng, A., Manda, B., and Mvula, R. L. S.: Lower crustal earthquakes in the East African Rift System: Insights from frictional properties of rock samples from the Malawi rift, Tectonophysics, 767, 228167, https://doi.org/10.1016/j.tecto.2019.228167, 2019.

Hodge, M., Biggs, J., Goda, K., and Aspinall, W.: Assessing infrequent large earthquakes using geomorphology and geodesy: the Malawi Rift, Nat. Hazards, 76, 1781-1806, https://doi.org/10.1007/s11069-014-1572-y, 2015.

Hodge, M., Fagereng, A., Biggs, J., and Mdala, H.: Controls on Early-Rift Geometry: New Perspectives From the BililaMtakataka Fault, Malawi, Geophys. Res. Lett., 45, 3896-3905, https://doi.org/10.1029/2018GL077343, 2018a.

Hodge, M., Fagereng, Å., and Biggs, J.: The Role of Coseismic Coulomb Stress Changes in Shaping the Hard Link Between Normal Fault Segments, J. Geophys. Res.-Sol. Ea., 123, 797814, https://doi.org/10.1002/2017JB014927, 2018 b.

Hodge, M., Biggs, J., Fagereng, Å., Elliott, A., Mdala, H., and Mphepo, F.: A semi-automated algorithm to quantify scarp morphology (SPARTA): application to normal faults in southern Malawi, Solid Earth, 10, 27-57, https://doi.org/10.5194/se-1027-2019, 2019.

Hodge, M., Biggs, J., Fagereng, Mdala, H., Wedmore, L. N. J., and Williams, J. N.: Evidence From High-Resolution Topography for Multiple Earthquakes on High Slip-to-Length Fault Scarps: The Bilila-Mtakataka Fault, Malawi, Tectonics, 39, e2019TC005933, https://doi.org/10.1029/2019TC005933, 2020.

Iezzi, F., Roberts, G., Walker, J. F., and Papanikolaou, I.: Occurrence of partial and total coseismic ruptures of segmented normal fault systems: Insights from the Central Apennines, Italy, J. Struct. Geol., 126, 83-99, https://doi.org/10.1016/j.jsg.2019.05.003, 2019.

Ivory, S. J., Blome, M. W., King, J. W., McGlue, M. M., Cole, J. E., and Cohen, A. S.: Environmental change explains cichlid adaptive radiation at Lake Malawi over the past 1.2 million years, P. Natl. Acad. Sci. USA, 113, 11895-11900, https://doi.org/10.1073/pnas.1611028113, 2016.

Jackson, J.: Living with earthquakes: Know your faults, J. Earthq. Eng., 5, 5-123, https://doi.org/10.1080/13632460109350530, 2001.

Jackson, J. and Blenkinsop, T.: The Malawi Earthquake of March 10, 1989: Deep faulting within the East African Rift System, Tectonics, 12, 1131-1139, https://doi.org/10.1029/93TC01064, 1993.

Jackson, J. and Blenkinsop, T.: The Bilila-Mtakataka fault in Malawi: an active, 100-km long, normal fault segment in thick seismogenic crust, Tectonics, 16, 137-150, https://doi.org/10.1029/96TC02494, 1997.

Jackson, J. A. and White, N. J.: Normal faulting in the upper continental crust: observations from regions of active extension, J. Struct. Geol., 11, 15-36, https://doi.org/10.1016/01918141(89)90033-3, 1989.

Jomard, H., Cushing, E. M., Palumbo, L., Baize, S., David, C., and Chartier, T.: Transposing an active fault database into a seismic hazard fault model for nuclear facilities - Part 1: Building a database of potentially active faults (BDFA) for metropoli- 
$\tan$ France, Nat. Hazards Earth Syst. Sci., 17, 1573-1584, https://doi.org/10.5194/nhess-17-1573-2017, 2017.

Kagan, Y. Y., Jackson, D. D., and Geller, R. J.: Characteristic earthquake model, 1884-2011, R.I.P., Seismol. Res. Lett., 83, 951953, https://doi.org/10.1785/0220120107, 2012.

King, A. W. and Dawson, A. L.: The Geology of the MangochiMakanjila Area, Bull. Geol. Surv. Malawi, 35, 69 pp., 1976.

Kloukinas, P., Novelli, V., Kafodya, I., Ngoma, I., Macdonald, J., and Goda, K.: A building classification scheme of housing stock in Malawi for earthquake risk assessment, J. Hous. Built Environ., 35, 507-537, https://doi.org/10.1007/s10901-019-09697-5, 2020.

Kolawole, F., Atekwana, E. A., Laó-Dávila, D. A., Abdelsalam, M. G., Chindandali, P. R., Salima, J., and Kalindekafe, L.: Active Deformation of Malawi Rift's North Basin Hinge Zone Modulated by Reactivation of Preexisting Precambrian Shear Zone Fabric, Tectonics, 37, 683-704, https://doi.org/10.1002/2017TC004628, 2018a.

Kolawole, F., Atekwana, E. A., Laó-Dávila, D. A., Abdelsalam, M. G., Chindandali, P. R., Salima, J., and Kalindekafe, L.: High-resolution electrical resistivity and aeromagnetic imaging reveal the causative fault of the $2009 \mathrm{Mw} 6.0$ Karonga, Malawi earthquake, Geophys. J. Int., 213, 1412-1425, https://doi.org/10.1093/gji/ggy066, 2018b.

Langridge, R. M., Ries, W. F., Litchfield, N. J., Villamor, P., Van Dissen, R. J., Barrell, D. J. A., Rattenbury, M. S., Heron, D. W., Haubrock, S., Townsend, D. B., Lee, J. M., Berryman, K. R., Nicol, A., Cox, S. C., and Stirling, M. W.: The New Zealand Active Faults Database, New Zeal. J. Geol. Geophys., 59, 86-96, https://doi.org/10.1080/00288306.2015.1112818, 2016.

Laõ-Dávila, D. A., Al-Salmi, H. S., Abdelsalam, M. G., and Atekwana, E. A.: Hierarchical segmentation of the Malawi Rift: The influence of inherited lithospheric heterogeneity and kinematics in the evolution of continental rifts, Tectonics, 34, 2399-2417, https://doi.org/10.1002/2015TC003953, 2015.

Lavayssière, A., Drooff, C., Ebinger, C., Gallacher, R., IllsleyKemp, F., Oliva, S. J., and Keir, D.: Depth Extent and Kinematics of Faulting in the Southern Tanganyika Rift, Africa, Tectonics, 38, 842-862, https://doi.org/10.1029/2018TC005379, 2019.

Leonard, M.: Earthquake fault scaling: Self-consistent relating of rupture length, width, average displacement, and moment release, B. Seismol. Soc. Am., 100, 1971-1988, https://doi.org/10.1785/0120090189, 2010.

Litchfield, N., Van Dissen, R., Sutherland, R., Barnes, P., Cox, S., Norris, R., Beavan, R., Langridge, R., Villamor, P., Berryman, K., Stirling, M., Nicol, A., Nodder, S., Lamarche, G., Barrell, D., Pettinga, J., Little, T., Pondard, N., Mountjoy, J., and Clark, K.: A model of active faulting in New Zealand, New Zeal. J. Geol. Geophys., 57, 32-56, https://doi.org/10.1080/00288306.2013.854256, 2014.

Litchfield, N. J., Villamor, P., van Dissen, R. J., Nicol, A., Barnes, P. M., Barrell, D. J. A., Pettinga, J. R., Langridge, R. M., Little, T. A., Mountjoy, J. J., Ries, W. F., Rowland, J., Fenton, C., Stirling, M. W., Kearse, J., Berryman, K. R., Cochran, U. A., Clark, K. J., Hemphill-Haley, M., Khajavi, N., Jones, K. E., Archibald, G., Upton, P., Asher, C., Benson, A., Cox, S. C., Gasston, C., Hale, D., Hall, B., Hatem, A. E., Heron, D. W., Howarth, J., Kane, T. J., Lamarche, G., Lawson, S., Lukovic, B., McColl, S. T., Madugo, C., Manousakis, J., Noble, D., Pedley, K., Sauer, K., Stahl, T.,
Strong, D. T., Townsend, D. B., Toy, V., Williams, J., Woelz, S., and Zinke, R.: Surface rupture of multiple crustal faults in the 2016 Mw 7.8 Kaikoura, New Zealand, earthquake, B. Seismol. Soc. Am., 108, 1496-1520, https://doi.org/10.1785/0120170300, 2018.

Lyons, R. P., Scholz, C. A., Cohen, A. S., King, J. W., Brown, E. T., Ivory, S. J., Johnson, T. C., Deino, A. L., Reinthal, P. N., McGlue, M. M., and Blome, M. W.: Continuous 1.3-million-year record of East African hydroclimate, and implications for patterns of evolution and biodiversity, P. Natl. Acad. Sci. USA, 112, 1556815573, https://doi.org/10.1073/pnas.1512864112, 2015.

Macgregor, D.: History of the development of the East African Rift System: A series of interpreted maps through time, J. African Earth Sci., 101, 232-252, https://doi.org/10.1016/j.jafrearsci.2014.09.016, 2015.

Machette, M., Haller, K., and Wald, L.: Quaternary Fault and Fold Database for the nation, United States Geological Survey Fact Sheet, available at: https://pubs.er.usgs.gov/publication/ fs20043033 (last access: 7 January 2021), 2004.

Macheyeki, A. S., Mdala, H., Chapola, L. S., Manhiça, V. J., Chisambi, J., Feitio, P., Ayele, A., Barongo, J., Ferdinand, R. W., Ogubazghi, G., Goitom, B., Hlatywayo, J. D., Kianji, G. K., Marobhe, I., Mulowezi, A., Mutamina, D., Mwano, J. M., Shumba, B., and Tumwikirize, I.: Active fault mapping in Karonga-Malawi after the December 19, 2009 Ms 6.2 seismic event, J. African Earth Sci., 102, 233-246, https://doi.org/10.1016/j.jafrearsci.2014.10.010, 2015.

Malawi, N. S. O.: 2018 Malawi Population \& Housing Census Main Report, Gov. Malawi, 299 pp., 2018.

Manda, B. W. C., Cawood, P. A., Spencer, C. J., Prave, T., Robinson, R., and Roberts, N. M. W.: Evolution of the Mozambique Belt in Malawi constrained by granitoid U-Pb, Sm$\mathrm{Nd}$ and Lu-Hf isotopic data, Gondwana Res., 68, 93-107, https://doi.org/10.1016/j.gr.2018.11.004, 2019.

McCalpin, J. P.: Paleoseismology, Academic press., 629 pp., 2009.

McCartney, T. and Scholz, C. A.: A 1.3 million year record of synchronous faulting in the hangingwall and border fault of a halfgraben in the Malawi (Nyasa) Rift, J. Struct. Geol., 91, 114-129, https://doi.org/10.1016/j.jsg.2016.08.012, 2016.

Mesko, G.: Magmatism at the Southern End of the East African Rift System: Origin and Role During Early Stage Rifting, 311 pp., 2020.

Midzi, V., Hlatywayo, D. J., Chapola, L. S., Kebede, F., Atakan, K., Lombe, D. K., Turyomurugyendo, G., and Tugume, F. A.: Seismic hazard assessment in Eastern and Southern Africa, Ann. di Geofis., 42, 1067-1083, https://doi.org/10.4401/ag-3770, 1999.

Molnar, P.: Earthquake recurrence intervals and plate tectonics, B. Seismol. Soc. Am., 69, 115-133, 1979.

Morell, K. D., Styron, R., Stirling, M., Griffin, J., Archuleta, R., and Onur, T.: Seismic hazard analyses from geologic and geomorphic data: Current and future challenges, Tectonics, 39, e2018TC005365, https://doi.org/10.1029/2018tc005365, 2020.

Morley, C. K.: Variable extension in Lake Tanganyika, Tectonics, 7 , 785-801, https://doi.org/10.1029/TC007i004p00785, 1988.

Mortimer, E. J., Paton, D. A., Scholz, C. A., Strecker, M. R., and Blisniuk, P.: Orthogonal to oblique rifting: Effect of rift basin orientation in the evolution of the North basin, Malawi Rift, East Africa, Basin Res., 19, 393-407, https://doi.org/10.1111/j.13652117.2007.00332.x, 2007. 
Mortimer, E. J., Kirstein, L. A., Stuart, F. M., and Strecker, M. R.: Spatio-temporal trends in normal-fault segmentation recorded by low-temperature thermochronology: Livingstone fault scarp, Malawi Rift, East African Rift System, Earth Planet. Sc. Lett., 455, 62-72, https://doi.org/10.1016/j.epsl.2016.08.040, 2016.

Muirhead, J. D., Kattenhorn, S. A., Lee, H., Mana, S., Turrin, B. D., Fischer, T. P., Kianji, G., Dindi, E., and Stamps, D. S.: Evolution of upper crustal faulting assisted by magmatic volatile release during early-stage continental rift development in the East African Rift, Geosphere, 12, 1670-1700, https://doi.org/10.1130/GES01375.1, 2016.

Muirhead, J. D., Wright, L. J. M., and Scholz, C. A.: Rift evolution in regions of low magma input in East Africa, Earth Planet. Sc. Lett., 506, 332-346, https://doi.org/10.1016/j.eps1.2018.11.004, 2019.

Ngoma, I., Kafodya, I., Kloukinas, P., Novelli, V., Macdonald, J., and Goda, K.: Building classification and seismic vulnerability of current housing construction in Malawi, Malawi J. Sci. Technol., 11, 57-72, 2019.

Nicol, A., Walsh, J. J., Watterson, J., and Underhill, J. R.: Displacement rates of normal faults, Nature, 390, 157-159, https://doi.org/10.1038/36548, 1997.

Nicol, A., Walsh, J., Berryman, K., and Villamor, P.: Interdependence of fault displacement rates and paleoearthquakes in an active rift, Geology, 34, 865-868, https://doi.org/10.1130/G22335.1, 2006.

Nicol, A., Van Dissen, R. J., Stirling, M. W., and Gerstenberger, M. C.: Completeness of the Paleoseismic Active-Fault Record in New Zealand, Seismol. Res. Lett., 87, 1299-1310, https://doi.org/10.1785/0220160088, 2016a.

Nicol, A., Robinson, R., Van Dissen, R. J., and Harvison, A.: Variability of recurrence interval and singleevent slip for surface-rupturing earthquakes in New Zealand, New Zeal. J. Geol. Geophys., 59, 97-116, https://doi.org/10.1080/00288306.2015.1127822, 2016b.

Njinju, E. A., Kolawole, F., Atekwana, E. A., Stamps, D. S., Atekwana, E. A., Abdelsalam, M. G., and Mickus, K. L.: Terrestrial heat flow in the Malawi Rifted Zone, East Africa: Implications for tectono-thermal inheritance in continental rift basins, J. Volcanol. Geotherm. Res., 387, https://doi.org/10.1016/j.jvolgeores.2019.07.023, 2019.

Novelli, V., Kloukinas, P., De Risi, R., Kafodya, I., Ngoma, I., Macdonald, J., and Goda, K.: Seismic Mitigation Framework for Non-engineered Masonry Buildings in Developing Countries: Application to Malawi in the East African Rift, in Resilient Structures and Infrastructure, Springer, 195-223, 2019.

Nyblade, A. A. and Langston, C. A.: East African earthquakes below $20 \mathrm{~km}$ depth and their implications for crustal structure, Geophys. J. Int., 121, 49-62, https://doi.org/10.1111/j.1365246X.1995.tb03510.x, 1995.

Olive, J. A., Behn, M. D., and Malatesta, L. C.: Modes of extensional faulting controlled by surface processes, Geophys. Res. Lett., 41, 6725-6733, https://doi.org/10.1002/2014GL061507, 2014.

Page, M. and Felzer, K.: Southern San Andreas fault seismicity is consistent with the Gutenberg-Richter magnitudefrequency distribution, B. Seismol. Soc. Am., 105, 2070-2080, https://doi.org/10.1785/0120140340, 2015.
De Pascale, G. P., Araya, J., Perisco, M., Sandoval, F., Sepulveda, S., and Moncada, D.: New school faults and seismic hazard, guilty (i.e. active) until proven innocent (i.e. inactive), in: PATA DAYS 2017; 8th International Workshop on Paleoseismology, Active Tectonics and Archeoseismology, 13-16 November 2017, Blenheim, New Zealand, 2017.

Pérouse, E. and Wernicke, B. P.: Spatiotemporal evolution of fault slip rates in deforming continents: The case of the Great Basin region, northern Basin and Range province, Geosphere, 13, 112135, https://doi.org/10.1130/GES01295.1, 2017.

Philippon, M., Willingshofer, E., Sokoutis, D., Corti, G., Sani, F., Bonini, M., and Cloetingh, S.: Slip re-orientation in oblique rifts, Geology, 43, 147-150, https://doi.org/10.1130/G36208.1, 2015.

Pike, J. G.: A pre-colonial history of Malawi, Nyasal. J., 18, 22-54, 1965.

Poblet, J. and Lisle, R. J.: Kinematic evolution and structural styles of fold-and-thrust belts, Geol. Soc. Spec. Publ., 349, 1-24, https://doi.org/10.1144/SP349.1, 2011.

Poggi, V., Durrheim, R., Tuluka, G. M., Weatherill, G., Gee, R., Pagani, M., Nyblade, A., and Delvaux, D.: Assessing seismic hazard of the East African Rift: a pilot study from GEM and AfricaArray, Bull. Earthq. Eng., 1-31, https://doi.org/10.1007/s10518-017-0152-4, 2017.

Quigley, M., Van Dissen, R., Litchfield, N., Villamor, P., Duffy, B., Barrell, D., Furlong, K., Stahl, T., Bilderback, E., and Noble, D.: Surface rupture during the $2010 \mathrm{Mw} 7.1$ darfield(canterbury) earthquake: Implications for fault rupture dynamics and seismic-hazard analysis, Geology, 40, 55-58, https://doi.org/10.1130/G32528.1, 2012.

Rabinowitz, N. and Steinberg, D. M.: Seismic hazard sensitivity analysis: a multi-parameter approach, B. Seismol. Soc. Am., 81, 796-817, 1991.

Roberts, E. M., Stevens, N. J., O’Connor, P. M., Dirks, P. H. G. M., Gottfried, M. D., Clyde, W. C., Armstrong, R. A., Kemp, A. I. S., and Hemming, S.: Initiation of the western branch of the East African Rift coeval with the eastern branch, Nat. Geosci., 5, 289-294, https://doi.org/10.1038/ngeo1432, 2012.

Robertson, E. A. M., Biggs, J., Cashman, K. V., Floyd, M. A., and Vye-Brown, C.: Influence of regional tectonics and pre-existing structures on the formation of elliptical calderas in the Kenyan Rift, Geol. Soc. Spec. Publ., 420, 43-67, 2016.

Sandwell, D., Mellors, R., Tong, X., Wei, M., and Wessel, P.: Open radar interferometry software for mapping surface Deformation, Eos, Trans. Am. Geophys. Union, 92, 234-234, https://doi.org/10.1029/2011EO280002, 2011.

Saria, E., Calais, E., Altamimi, Z., Willis, P., and Farah, H.: A new velocity field for Africa from combined GPS and DORIS space geodetic Solutions: Contribution to the definition of the African reference frame (AFREF), J. Geophys. Res.-Sol. Ea., 118, 16771697, https://doi.org/10.1002/jgrb.50137, 2013.

Saria, E., Calais, E., Stamps, D. S., Delvaux, D., and Hartnady, C. J. H.: Present-day kinematics of the East African Rift, J. Geophys. Res.-Sol. Ea., 119, 3584-3600, https://doi.org/10.1002/2013JB010901, 2014.

Scholz, C., Shillington, D., Wright, L., Accardo, N., Gaherty, J., and Chindandali, P.: Intrarift fault fabric, segmentation, and basin evolution of the Lake Malawi (Nyasa) Rift, East Africa, Geosphere, 16, 1293-1311, https://doi.org/10.1130/GES02228.1, 2020 . 
Scholz, C. H.: The Mechanics of Earthquakes and Faulting, 2 Edn., Cambridge University Press, Cambridge, 504 pp., 2002.

Scholz, C. H. and Contreras, J. C.: Mechanics of continental rift architecture, Geology, 26, 967-970, https://doi.org/10.1130/00917613(1998)026<0967:MOCRA>2.3.CO, 1998.

Scholz, C. H., Aviles, C. A., and Wesnousky, S. G.: Scaling differences between large interplate and intraplate earthquakes, B. Seismol. Soc. Am., 76, 65-70, https://doi.org/10.1144/gsjgs.141.4.0763, 1986.

Shillington, D. J., Scholz, C. A., Chindandali, P. R. N., Gaherty, J. B., Accardo, N. J., Onyango, E., Ebinger, C. J., and Nyblade, A. A.: Controls on Rift Faulting in the North Basin of the Malawi (Nyasa) Rift, East Africa, Tectonics, 39, e2019TC005633, https://doi.org/10.1029/2019TC005633, 2020.

Shudofsky, G. N., Cloetingh, S., Stein, S., and Wortel, R.: Unusually deep earthquakes in East Africa: Constraints on the thermomechanical structure of a continental rift system, Geophys. Res. Lett., 14, 741-744, https://doi.org/10.1029/GL014i007p00741, 1987.

Shyu, J. B. H., Chuang, Y. R., Chen, Y. L., Lee, Y. R., and Cheng, C. T.: A new on-land seismogenic structure source database from the Taiwan earthquake model (TEM) project for seismic hazard analysis of Taiwan, Terr. Atmos. Ocean. Sci., 27, 311-323, https://doi.org/10.3319/TAO.2015.11.27.02(TEM), 2016.

Sibson, R. H.: Earthquake faulting as a structural process, J. Struct. Geol., 11, 1-14, https://doi.org/10.1016/0191-8141(89)90032-1, 1989.

Siegburg, M., Bull, J. M., Nixon, C. W., Keir, D., Gernon, T. M., Corti, G., Abebe, B., Sanderson, D. J., and Ayele, A.: Quantitative Constraints on Faulting and Fault Slip Rates in the Northern Main Ethiopian Rift, Tectonics, 39, e2019TC006046, https://doi.org/10.1029/2019TC006046, 2020.

Stahl, K.: Some notes on the development of Zomba, Soc. Malawi J., 63, 39-55, 2010.

Stamps, D. S., Calais, E., Saria, E., Hartnady, C., Nocquet, J. M., Ebinger, C. J., and Fernandes, R. M.: A kinematic model for the East African Rift, Geophys. Res. Lett., 35, L05304, doi10.1029/2007GL032781, 2008.

Stamps, D. S., Saria, E., and Kreemer, C.: A Geodetic Strain Rate Model for the East African Rift System, Sci. Rep., 8, 732, https://doi.org/10.1038/s41598-017-19097-w, 2018.

Stamps, D. S., Kreemer, C., Fernandes, R., Rajaonarison, T. A., and Rambolamanana, G.: Redefining East African Rift System kinematics, Geology, 49, https://doi.org/10.1130/g47985.1, 2020.

Stein, S., Geller, R. J., and Liu, M.: Why earthquake hazard maps often fail and what to do about it, Tectonophysics, 562, 1-25, https://doi.org/10.1016/j.tecto.2012.06.047, 2012.

Steinbruch, F.: Geology and geomorphology of the Urema Graben with emphasis on the evolution of Lake Urema, J. African Earth Sci., 58, 272-284, https://doi.org/10.1016/j.jafrearsci.2010.03.007, 2010.

Stirling, M. and Gerstenberger, M.: Applicability of the Gutenberg-Richter relation for major active faults in New Zealand, B. Seismol. Soc. Am., 108, 718-728, https://doi.org/10.1785/0120160257, 2018.

Stirling, M., McVerry, G., Gerstenberger, M., Litchfield, N., Van Dissen, R., Berryman, K., Barnes, P., Wallace, L., Villamor, P., Langridge, R., Lamarche, G., Nodder, S., Reyners, M., Bradley, B., Rhoades, D., Smith, W., Nicol, A., Pettinga, J., Clark,
K., and Jacobs, K.: National seismic hazard model for New Zealand: 2010 update, B. Seismol. Soc. Am., 102, 1514-1542, https://doi.org/10.1785/0120110170, 2012.

Styron, R. and Pagani, M.: The GEM Global Active Faults Database, Earthq. Spectra, 1-21, https://doi.org/10.1177/8755293020944182, 2020.

Styron, R., García-Pelaez, J., and Pagani, M.: CCAF-DB: The Caribbean and Central American active fault database, Nat. Hazards Earth Syst. Sci., 20, 831-857, https://doi.org/10.5194/nhess20-831-2020, 2020.

Taylor-Silva, B. I., Stirling, M. W., Litchfield, N. J., Griffin, J. D., van den Berg, E. J., and Wang, N.: Paleoseismology of the Akatore Fault, Otago, New Zealand, New Zeal. J. Geol. Geophys., 63, 151-167, https://doi.org/10.1080/00288306.2019.1645706, 2020.

Taylor, M. and Yin, A.: Active structures of the Himalayan-Tibetan orogen and their relationships to earthquake distribution, contemporary strain field, and Cenozoic volcanism, Geosphere, 5, 199-214, https://doi.org/10.1130/GES00217.1, 2009.

U.S. Department of the Interior U.S. Geological Survey: M 5.5 $24 \mathrm{~km}$ NE of Nsanje, Malawi, available at: https://earthquake. usgs.gov/earthquakes/eventpage/us1000d1cy\#executive, last access: 26 September 2018.

Valentini, A., DuRoss, C. B., Field, E. H., Gold, R. D., Briggs, R. W., Visini, F., and Pace, B.: Relaxing Segmentation on the Wasatch Fault Zone: Impact on Seismic Hazard, B. Seismol. Soc. Am., 110, 83-109, https://doi.org/10.1785/0120190088, 2020.

Vallage, A. and Bollinger, L.: Testing Fault Models in Intraplate Settings: A Potential for Challenging the Seismic Hazard Assessment Inputs and Hypothesis?, Pure Appl. Geophys., 177, 187991889, https://doi.org/10.1007/s00024-019-02129-z, 2019.

Van Bocxlaer, B., Salenbien, W., Praet, N., and Verniers, J.: Stratigraphy and paleoenvironments of the early to middle Holocene Chipalamawamba Beds (Malawi Basin, Africa), Biogeosciences, 9, 4497-4512, https://doi.org/10.5194/bg-9-4497-2012, 2012.

Villamor, P., Litchfield, N., Barrell, D., Van Dissen, R., Hornblow, S., Quigley, M., Levick, S., Ries, W., Duffy, B., Begg, J., Townsend, D., Stahl, T., Bilderback, E., Noble, D., Furlong, K., and Grant, H.: Map of the 2010 Greendale Fault surface rupture, Canterbury, New Zealand: Application to land use planning, New Zeal. J. Geol. Geophys., 55, 223-230, https://doi.org/10.1080/00288306.2012.680473, 2012.

Villamor, P., Barrell, D. J. A., Gorman, A., Davy, B., Hreinsdóttir, S., Hamling, I. J., Stirling, M. W., Cox, S. C., Litchfield, N. J., Holt, A., Todd, E., Denys, P., Pearson, C., C, S., GarciaMayordomo, J., Goded, T., Abbot, E., Ohneiser, C., Lepine, P., and Caratori-Tontini, F.: Unknown faults under cities, Lower Hutt, 71 pp., 2018.

Wallace, L. M., Barnes, P., Beavan, J., Van Dissen, R., Litchfield, N., Mountjoy, J., Langridge, R., Lamarche, G., and Pondard, N.: The kinematics of a transition from subduction to strike-slip: An example from the central New Zealand plate boundary, J. Geophys. Res.-Sol. Ea., 117, B02405, https://doi.org/10.1029/2011JB008640, 2012.

Wallace, R. E.: Earthquake recurrence intervals on the San Andreas fault, Bull. Geol. Soc. Am., 81, 2875-2890, https://doi.org/10.1130/00167606(1970)81[2875:ERIOTS]2.0.CO;2, 1970. 
Wallace, R. W.: Degradation of the Hebgen Lake fault scarps of 1959, Geology, 8, 225-229, https://doi.org/10.1130/00917613(1980)8<225:DOTHLF>2.0.CO;2, 1980.

Walshaw, R. D.: The Geology of the Nchue-Balaka Area, Bull. Geol. Surv. Malawi, 19, 96 pp., 1965.

Wedmore, L. N. J., Biggs, J., Williams, J. N., Fagereng, Dulanya, Z., Mphepo, F., and Mdala, H.: Active Fault Scarps in Southern Malawi and Their Implications for the Distribution of Strain in Incipient Continental Rifts, Tectonics, 39, e2019TC005834, https://doi.org/10.1029/2019TC005834, 2020a.

Wedmore, L. N. J., Williams, J. N., Biggs, J., Fagereng, Å., Mphepo, F., Dulanya, Z., Willoughby, J., Mdala, H., and Adams, B. A.: Structural inheritance and border fault reactivation during active early-stage rifting along the Thyolo fault, Malawi, J. Struct. Geol., 139, 104097, https://doi.org/10.1016/j.jsg.2020.104097, 2020b.

Wells, D. L. and Coppersmith, K. J.: New Empirical Relationships among Magnitude, Rupture Length, Rupture Width, Rupture Area, and Surface Displacement, B. Seismol. Soc. Am., 84, 974-1002, 1994.

Wesnousky, S. G.: Displacement and geometrical characteristics of earthquake surface ruptures: Issues and implications for seismic-hazard analysis and the process of earthquake rupture, B. Seismol. Soc. Am., 98, 1609-1632, https://doi.org/10.1785/0120070111, 2008.

Wessel, B., Huber, M., Wohlfart, C., Marschalk, U., Kosmann, D., and Roth, A.: Accuracy assessment of the global TanDEM-X Digital Elevation Model with GPS data, ISPRS J. Photogramm. Remote Sens., 139, 171-182, 2018.

Wheeler, W. H. and Rosendahl, B. R.: Geometry of the Livingstone Mountains Border Fault, Nyasa (Malawi) Rift, East Africa, Tectonics, 13, 303-312, https://doi.org/10.1029/93TC02314, 1994.

Willemse, E. J. M.: Segmented normal faults: Correspondence between three-dimensional mechanical models and field data, J. Geophys. Res.-Sol. Ea., 102, 675-692, 1997.

Williams, J. N., Fagereng, Å., Wedmore, L. N. J., Biggs, J., Mphepo, F., Dulanya, Z., Mdala, H., and Blenkinsop, T.: How Do Variably Striking Faults Reactivate During Rifting?, Insights From Southern Malawi, Geochem. Geophys. Geosys., 20, 35883607, https://doi.org/10.1029/2019GC008219, 2019.
Tectonic Shift RIFT2018 Report: International Bank for Reconstruction and Development/International Development Association or The World Bank, available at: https://www.gfdrr.org/en/ pulication/tectonic-shift-rift2018-report (last access: 6 January 2021), 1818 H Street NW, Washington DC, 20433, 2019.

WorldPop: School of Geography and Environmental Science, University of Southampton; Department of Geography and Geosciences, University of Louisville; Departement de Geographie, Universite de Namur and Center for International Earth Science Info, https://doi.org/10.5258/SOTON/WP00538, 2018.

Wright, L. J. M., Muirhead, J. D., and Scholz, C. A.: Spatio-temporal variations in upper crustal extension across the different basement terranes of the Lake Tanganyika Rift, East Africa, Tectonics, 39, e2019TC006019, https://doi.org/10.1029/2019tc006019, 2020.

Yeats, R.: Active faults of the world, Cambridge University Press, 634 pp., 2012.

Youngs, R. R. and Coppersmith, K. J.: Implications of fault slip rates and earthquake recurrence models to probabilistic seismic hazard estimates, B. Seismol. Soc. Am., 75, 939-964, 1985.

Zeng, Y. and Shen, Z. K.: Fault network modeling of crustal deformation in California constrained using GPS and geologic observations, Tectonophysics, 612, 1-17, https://doi.org/10.1016/j.tecto.2013.11.030, 2014.

Zhang, P., Slemmons, D. B., and Mao, F.: Geometric pattern, rupture termination and fault segmentation of the Dixie ValleyPleasant Valley active normal fault system, Nevada, USA, J. Struct. Geol., 13, 165-176, https://doi.org/10.1016/01918141(91)90064-P, 1991.

Zielke, O. and Strecker, M. R.: Recurrence of large earthquakes in magmatic continental rifts: Insights from a paleoseismic study along the Laikipia-Marmanet fault, Subukia Valley, Kenya rift, B. Seismol. Soc. Am., 99, 61-70, https://doi.org/10.1785/0120080015, 2009. 